\begin{tabular}{|c|c|c|}
\hline()$_{\text {SiipT }}^{\prime}$ & $\begin{array}{c}\text { Türkiye Tarımsal Araştırmalar Dergisi } \\
\text { dergipark.org.tr/tutad }\end{array}$ & $\begin{array}{l}\text { Turk J Agric Res } \\
\text { 2021, 8(1): 56-74 } \\
\text { ○ TÜTAD } \\
\text { ISSN: 2148-2306 }\end{array}$ \\
\hline $\begin{array}{l}\text { UNNIVERSiTESi } \\
\text { Bulimin Psüynda }\end{array}$ & Research Article & $\begin{array}{l}\text { e-ISSN: } 2528-858 X \\
\text { doi: 10.19159/tutad.810375 }\end{array}$ \\
\hline
\end{tabular}

\title{
Spatial Market Integration of Rice in the World
}

\author{
Mohammed Sanusi SADIQ ${ }^{1 *}$, Invinder Paul SINGH ${ }^{2}$, Muhammad Makarfi AHMAD ${ }^{3}$ \\ ${ }^{I}$ Federal University Dutse, Department of Agricultural Economics and Extension, Dutse, NIGERIA \\ ${ }^{2}$ Swami Keshwanand Rajasthan Agricultural University, Department of Agricultural Economics, Bikaner, INDIA \\ ${ }^{3}$ Bayero University Kano, Department of Agricultural Economics, Kano, NIGERIA
}

\begin{tabular}{l}
\hline Received: $14.10 .2020 \quad$ Accepted: 14.02 .2021 \\
\hline ORCID ID (by author order) \\
(iD orcid.org/0000-0003-4336-5723 (D) orcid.org/0000-0002-1886-5956 (D) orcid.org/0000-0003-4565-0683 \\
${ }^{*}$ Corresponding Author: sadiqsanusi30@gmail.com
\end{tabular}

\begin{abstract}
Time series data (1966 to 2017) that covered prices of six selected major exporting rice markets in the world were used to determine the integration of rice markets in the world. The collected data were analyzed using both descriptive and inferential statistics. In spite of the long-run price association among the selected six markets, the poor extent of market cointegration made the law of one price (LOP) not to hold i.e. elusive in these markets. Except for Pakistan and China markets, all the remaining markets were quite competitive as they have a high degree of market integration- stable equilibrium that absolved any short-run shocks that generate discontinuity and asymmetric price responses. Pakistan market has a dominant role in price formation of all its contemporary five markets while China market viz. leverage effect (inventory accumulation) is not affected by any local shock that emanated from the five markets. However, the local shock generated from China market is felt by all the selected markets. Furthermore, it was observed that international trade in rice marketing is very useful in Cambodian; USA, and China markets as volatility of their respective current prices was quite persistent. Based on the forecast, it can be inferred that the rice prices of the selected markets will adjust according to supply and demand. Therefore, for the development of a single integrated economic rice market in the world, there is a need to strengthen the linkages and interconnectedness among the major exporting rice markets for faster transmission of price and commodity management for efficient allocation. This can be achieved by enhancing the development of market infrastructure viz. assaying, grading, sorting, standardization, quality assurance, physio-sanitary standardization; use of e-trade and e-commerce, value addition, transportation, and other back-end supply chain.
\end{abstract}

Keywords: Market, integration, spatial, price, rice, volatility

\section{Introduction}

For insight into the functioning of markets, market integration in many agricultural commodities has been extensively studied (Sadiq et al., 2016a, 2017). These studies provide valuable data on market adaptation dynamics and whether there is a market imperfection that can justify government intervention (Sadiq et al., 2016b, 2020a).

To research market efficiency, spatial price relationships have been used extensively (Sadiq et al., 2017). The integration of the spatial and temporal market is an indicator of agricultural markets' efficient functioning (Reddy, 2012). Producers and consumers will not realize the potential gains from liberalization and globalization until agricultural markets are integrated. The successful functioning of markets provides producers with profitable prices and customers with equal prices (Mahalle et al., 2015). In the case of large producing and consuming countries, market integration and price transmission depend on geographical dispersion or concentration of output. Though buyers are scattered all over the globe, there is less scatteredout of demand and market surplus.

Hussainiet al. (2010) noted that the allocation of resources in a decentralized economic system takes place through price signals transmitted by the markets. Unless markets are integrated, price signals may be skewed, leading to inefficient resource allocation and marketable surpluses 
produced by farmers, thereby reducing farm prices and incomes. The agricultural market performance literature has shown that there are many barriers to the successful operation of these markets in emerging economies (Beag and Singla, 2014). The ongoing debate on effective agricultural marketing policies, government interference in the marketplace, determinants of the efficiency of agricultural marketing, and the need to estimate the effects of these determinants have made it possible for researchers to either change conventional techniques or establish methods to evaluate the market competence.

In an integrated agricultural market, the price of a commodity will be determined by the forces of supply and demand and will represent value when a good is traded on the world market throughout the integrated region or at the global level (Lanfrancoet al., 2019). Under the Law of One Price (LOP), the true value of a product (after exchange rate changes and transport cost accounting) would prevail through geographically dispersed markets located in one or more countries. Applying the LOP; it is possible to assess the geographic scope of a market and the degree of integration within a market and to identify and address points of chronic market integration failure. There will always be short-run deviations from LOP and variables such as exchange rate fluctuations and other "overshooting impacts" can explain them (Ardeni, 1989; Sadiq et al., 2018a; Lanfrancoet al., 2019). Markets are dynamic and constantly adjusting, but a single level of value will emerge when allowed to function and serve as a price signal throughout the integrated region.

Market integration is at the center of regional and global economic growth and is a core goal of regional trade blocs as well as of multilateral trade agreements. As a key justification for trade liberalization, the economic benefits of market integration have been promoted and substantial efforts have been made globally to reduce trade barriers, harmonize policies and regulations, and encourage trade in goods and services. However, in many industries and regions, market integration, and more specifically, integration into international markets remains a theoretical objective and a condition that is often derailed by larger forces.

From a continental viewpoint, with shipments amounting to $\$ 16.4$ billion, three-quarters (75 percent) of global rice exports originated from Asian nations (Sadiq et al., 2020b; Workman, 2020). During the forecast periods of 2019-2024, the rice market is expected to record a compound annual growth rate (CAGR) of 0.88 percent
(Anonymous, 2020). With more than 700 million metric tons produced annually globally, rice is the staple food of more than half of the world's population (Sadiq et al., 2018b, 2020b). In the Asian region, from Pakistan in the west to Japan in the east, most of the rice is grown and consumed. After wheat in the world, rice is the second most important cereal crop (Sadiq et al., 2018b). It is a crop that, in many developing countries in the regions of East Asia and Southeast Asia, ensures food security. The growth of the rice market is therefore expected to increase, as rice is the most consumed cereal grain globally (Sadiq et al., 2020b).

Global market integration has important implications for trade harmonization, government regulation, and economic policy in general. In this context, concerns remain as to whether these large rice markets are essentially a single integrated market, although spatially segmented, or whether the global rice market consists of distinct, independently operating markets. To what extent is the foreign market integrated if country-specific markets are relatively independent? Or as may be more important, to what extent are the various markets incorporated into the international market?

It is in view of the foregoing that this research was conceptualized to determine the market integration of rice among the major exporting countries in the world. The specific objectives were to: (I) examine the price trend of each of the selected markets; (II) to determine the extent of market integration among the selected markets; (III) to determine the degree of market integration among the selected markets; (IV) to examine the process of price formation in these markets; (V) to determine the effect of unexpected local shock on each market prices; (VI) to predict the future rice prices in each of the market; and, (VII) to determine the effect of volatility on the current year prices of each market.

\section{Materials and Methods}

Time series data which ranged from 1966 to 2017 and sourced from the FAO (Food and Agriculture Organization of the United Nations) databank were used for the study. The data covered six major rice exporting markets viz. China, Cambodia, India, Pakistan, Thailand, and USA. Both descriptive and inferential statistics were used for the data analysis. Descriptive statistics and multiple regression (ordinary least square-OLS and Autoregressive model) were used to achieve the objective I. While unit root tests, Engle and Granger co-integration, and Johansen cointegration tests were used to achieve objective II. 
Restricted Vector-Autoregression (VAR) was used to achieve objectives III and VI. Objectives IV and $\mathrm{V}$ were achieved using the Granger causality test and restricted VAR impulse response function, respectively. While objective VII was achieved using the Generalized Autoregression Conditional Heteroscedasticity (GARCH) model.

\subsection{Model specification}

Multiple regression: The model is given in Equation 1.

$$
P_{t}=\alpha+T_{t}+\varepsilon
$$

Where, $P_{t}$ is price at time ' $\mathrm{t}^{\prime}, \quad \alpha$ is constant, $T_{t}$ is time trend at time ' $\mathrm{t}$ ' and $\varepsilon$ is noise.

Augmented Dickey-Fuller (ADF) test: Following Sadiq et al. (2017) the autoregressive formulation of the ADF test with a trend term is given in Equation 2.

$$
\Delta P_{t}=\alpha+P_{t-1}+\sum_{j=2}^{i t} \beta_{i} \Delta P_{i t-j+t}+\varepsilon
$$

Where, $P_{i t}$ is the price in the market $i$ at the time $t, \alpha$ and $\Delta P_{i t}\left(P_{i t}-P_{t-1}\right)$ is the intercept or trend term.

Engle and Granger co-integration test: Following Engle and Granger (1987), the formulation test on residual from the co-integration test is given in Equation 3.

$$
P_{1}=\alpha+P_{2}+\varepsilon
$$

Where, $P_{1}$ and $P_{2}$ are the price series from different market, $\alpha$ is constant, and $\varepsilon$ is noise.

The residuals from the above equation are considered to be temporary deviations from the long-run equilibrium. ADF unit root test is then conducted on the residual obtained from Equation 3.

Johansen's co-integration test: Following Johansen (1988) the multivariate formulation is specified in Equation 4.

$$
P_{t}=A_{1} P_{t-1}+\varepsilon_{t}
$$

So that Equation 4 is expanded in Equation 5.

$$
\begin{aligned}
& \Delta P_{t}=A_{1} P_{t-1}-P_{t-1}+\varepsilon_{t} \\
& P_{t}=\left(A_{1}-1\right) P_{t-1}+\varepsilon_{t} \\
& \Delta P_{t}=\prod P_{t-1}+\varepsilon_{t}
\end{aligned}
$$

Where, $P_{t}$ and $\varepsilon_{t}$ are $(n \times 1)$ vectors; $A_{t}$ is an $(n \times n)$ matrix of parameters; $I$ is an $(n \times n)$ identity matrix, and $\prod$ is the $\left(A_{1}-1\right)$ matrix.

Using the estimates of the characteristic roots, the tests for the number of characteristic roots that are insignificantly different from unity were conducted using the statistics in Equations 6 and 7.

$$
\begin{aligned}
& \lambda_{\text {trace }}=-T \sum_{i=r+1}^{n} \ln \left(1-\lambda_{i}\right) \\
& \lambda_{\max }=-T \ln \left(1-\lambda_{i}+1\right)
\end{aligned}
$$

Where, $\lambda_{i}$ denotes the estimated values of the characteristic roots (Eigen-values) obtained from the estimated $\Pi$ matrix, and $T$ is the number of usable observations.

Granger causality test: Following Granger (1969) the model used to check whether the market $P_{1}$ Granger causes market $P_{2}$ or vice-versa is given in Equation 8.

$$
P_{t}=\alpha+\sum_{i=1}^{n}\left(\varnothing P_{1 t-i}+\delta_{i} P_{2 t-i}\right)+\varepsilon_{i}
$$

A simple test of the joint significance of $\delta_{i}$ was used to check the Granger causality i.e.

$$
H_{0}:=\delta_{1}=\delta_{2}=\ldots \ldots . \delta_{n}=0 .
$$

Vector error correction model (VECM): The VECM explains the difference in $y_{t}$ and $y_{t-1}$ (i.e. $\Delta y_{t}$ ) and it is shown in Equation 9 (Sadiq et al., 2016a, 2016b).

$$
\Delta \gamma_{t}=\alpha+\mu\left(\gamma_{t-1}-\beta_{x t-1}\right)+\sum_{i=0}^{i=t} \delta_{i} \Delta x_{t-1}+\sum_{i=1}^{i=t} \gamma_{i} \Delta \gamma_{t-1}
$$

It includes the lagged differences in both $x$ and $y$, which have a more immediate impact on the value of $\Delta \gamma_{t}$.

Impulse response functions: The generalized impulse response function (GIRF) in the case of an arbitrary current shock $(\delta)$ and history $\left(\omega_{t-1}\right)$ is specified in Equation 10 (Rahman and Shahbaz, 2013; Beag and Singla, 2014).

$$
\operatorname{GIRF}_{Y}\left(h, \delta, \omega_{t-1}\right)=E\left[Y_{t}+h \mid \delta, \omega_{t-1}\right]-E\left[Y_{t-1} \mid \omega_{t-1}\right]
$$

Forecasting accuracy: Mean absolute prediction error (MAPE), relative mean square prediction error (RMSPE), relative mean absolute prediction error (RMAPE) (Paul, 2014), Theil's U statistic, and $\mathrm{R}^{2}$ were determined using the formulas in Equations 11-15 to test accuracy in the fitted time series model. 


$$
\begin{aligned}
& \text { MAPE }=1 / T \sum_{i=1}^{5}\left(A_{t-1}-F_{t-1}\right) \\
& \text { RMPSE }=1 / T \sum_{i=1}^{5}\left(A_{t-1}-F_{t-1}\right)^{2} / A_{t-1} \\
& \text { RMAPE }=1 / T \sum_{i=1}^{5}\left(A_{t-1}-F_{t-1}\right) / A_{t-1} \times 100 \\
& U=\sqrt{\frac{\sum_{t=1}^{n-1} \frac{\left(\hat{Y}_{t+1}-Y_{t+1}\right)^{2}}{Y_{t}}}{\sum_{t=1}^{n-1} \frac{\left(Y_{t+1}-Y_{t}\right)^{2}}{Y_{t}}}} \\
& R^{2}=1-\frac{\sum_{i=1}^{n}\left(A_{t i}-F_{t i}\right)}{\sum_{i=1}^{n}\left(A_{t i}\right)}
\end{aligned}
$$

Where, $R^{2}$ is the coefficient of multiple determination, $A_{t}$ is actual value; $F_{t}$ is Future value, and $T$ is the time period.

GARCH model: The representation of the $\operatorname{GARCH}(p, q)$ is given in Equation 16.

$$
Y_{t}=\alpha+\beta_{1} Y_{t-1}+\beta_{2} Y_{t-2}+\varepsilon_{i} \text { (Autoregressive process) }
$$

And the variance of random error is given in Equations 17-18.

$$
\begin{aligned}
& \sigma_{t}^{2}=\lambda_{0}+\lambda_{1} \mu_{t-1}^{2}+\lambda_{2} \sigma_{t-1}^{2} \\
& \sigma_{t}^{2}=\omega+\sum_{i=1}^{p} \beta_{i} \sigma_{t-i}^{2}+\sum_{j=1}^{q} \alpha_{i} \varepsilon_{t-i}^{2}
\end{aligned}
$$

Where $Y_{t}$ is the price in the $i^{t h}$ period of the $i^{\text {th }}$ market, $p$ is the order of the GARCH term, and $q$ isthe order of the ARCH term. The sum of $\mathrm{ARCH}$ and GARCH $(\alpha+\beta)$ gives the degree of persistence of volatility in the series. The closer is the sum to 1; the greater is the tendency of volatility to persist for a longer time. If the sum exceeds1, it is indicative of an explosive series with a tendency to meander away from the mean value.

\section{Results and Discussion}

\subsection{Summary statistics of the market prices}

A perusal of the Table showed that the average values of rice prices varied from $\$ 195.34$ ton $^{-1}$ to $\$ 372360$ ton $^{-1}$ (Table 1). The Thailand market has the lowest market price while the Cambodian market has the highest market price. Also, the standard deviation of the prices was found to be highest and lowest in Cambodian and Thailand markets respectively. Furthermore, a cursory review of the results showed instability in prices to be moderate in the USA market; high in Thailand market; and very high in the remaining markets. Thus, it can be inferred that the USA market witnessed a moderate fluctuation in its average annual price per ton while the remaining markets witnessed a varied degree of high fluctuation in their annual average prices.

The coefficient of skewness provides details about the distribution of asymmetry. A value of 0 indicates a symmetrical distribution, while a positive (negative) value indicates a right-skewed (left) distribution. In general, grain prices display a positive skewness and this is fair as grain inventories cannot be negative, putting a positive skewness bias in the results. It can be inferred that rice is a storable commodity thus exhibiting positive rather than negative skewness. Stigler (2011), Sukati (2017) and Sadiq et al. (2020a) reported that floor prices tend to generate positive skewness whereas prices at the ceiling tend to encourage negative skewness. The existence of positive skewness from a realistic point of view will assist policy design in that positive price asymmetry means that one can be very secure in setting a minimum price level. All the selected markets have their tail distributions not thicker than normal. Excess kurtosis is characteristic of a market that exhibits extreme price values.

Table 1. Summary statistics of rice prices in the selected markets

\begin{tabular}{lrrrrrrr}
\hline Markets & \multicolumn{1}{c}{ Mean } & Minimum & Maximum & \multicolumn{1}{c}{ SD } & CV & Skewness & Kurtosis \\
\hline Cambodia & 2054.60 & 23.04 & 5420.70 & 1736.00 & 0.844 & 0.27626 & -1.52760 \\
India & 26.93 & 3.68 & 64.23 & 19.37 & 0.719 & 0.31611 & -1.47660 \\
Pakistan & 38.90 & 2.43 & 129.81 & 35.42 & 0.910 & 0.96093 & -0.13818 \\
Thailand & 18.78 & 3.92 & 37.11 & 7.68 & 0.409 & 0.15837 & -0.39978 \\
USA & 195.34 & 82.67 & 370.00 & 73.70 & 0.377 & 0.63450 & -0.49330 \\
China & 24.23 & 4.06 & 95.86 & 21.65 & 0.894 & 1.67110 & 2.11500 \\
\hline
\end{tabular}

SD: Standard deviation, CV: Coefficient of variation 


\subsection{Price trend of rice in the selected markets}

The price trend analysis was measured with both OLS and Auto-Regressive (Dynamic model) models using different mechanisms (Table 2). Generally, the results of the dynamic methods were found to be more reliable as evident from the diagnostic test statistics viz. Durbin-Watson and Langrage multiplier test statistics for autocorrelation and Arch effect which were different from zero at 10\% significance level. The results showed an increase in the prices of all the selected markets, except that of the China market which declined. However, the price trend of the China market was not significant, thus indicating the influence of the asymmetric effect on the price of the China market. The USA rice price has the lowest increase, followed by Thailand, Pakistan, and Indian market prices; while the Cambodian market had the highest price trend increase.

Table 2. Price trends of selected markets

\begin{tabular}{|c|c|c|c|c|c|c|}
\hline Markets & Methods & Intercept & Time trend & $\mathrm{R}^{2}$ & D-W stat & ARCH effect \\
\hline \multirow{8}{*}{ Cambodia } & \multirow{2}{*}{ OLS } & $-279464(46808.3)$ & $24597.2(1536.97)$ & \multirow[b]{2}{*}{0.8366} & \multirow[b]{2}{*}{0.192} & \multirow{2}{*}{$24.23[0.071]^{\mathrm{NS}}$} \\
\hline & & $5.970^{* * *}$ & $16.00^{* * *}$ & & & \\
\hline & \multirow{2}{*}{$\begin{array}{l}\text { Cochrane- } \\
\text { Orcutt }\end{array}$} & $-643942(243839)$ & $34450.7(6337.63)$ & \multirow{2}{*}{0.9713} & \multirow{2}{*}{2.178} & \multirow{2}{*}{$2.886[0.409]^{\mathrm{NS}}$} \\
\hline & & $2.641^{* * *}$ & $5.436^{* * *}$ & & & \\
\hline & \multirow{2}{*}{$\begin{array}{l}\text { Prais- } \\
\text { Winsten }\end{array}$} & $-194218(159275)$ & $23916.3(4718.92)$ & \multirow{2}{*}{0.9703} & \multirow{2}{*}{2.066} & \multirow{2}{*}{$2.81[0.244]^{\mathrm{NS}}$} \\
\hline & & $1.219^{\mathrm{NS}}$ & $5.068^{* * *}$ & & & \\
\hline & \multirow{2}{*}{ Hildreth-Lu } & $-644244(244031)$ & $34457.3(6341.68)$ & \multirow{2}{*}{0.9713} & \multirow{2}{*}{2.178} & \multirow{2}{*}{$2.86[0.239]^{\mathrm{NS}}$} \\
\hline & & $2.640^{* *}$ & $5.433^{* * *}$ & & & \\
\hline \multirow{6}{*}{ India } & \multirow{2}{*}{ OLS } & $-5559.25(1285.00)$ & $487.09(42.19)$ & \multirow{2}{*}{0.7271} & \multirow{2}{*}{0.038} & \multirow{2}{*}{$43.7[1.73 \mathrm{e}-9]^{* *}$} \\
\hline & & $4.326^{* * *}$ & $11.54^{* * *}$ & & & \\
\hline & Prais- & $-962.90(8402.57)$ & $568.55(116.22)$ & 0.9931 & & \\
\hline & Winsten & $0.114^{\mathrm{NS}}$ & $4.892^{* * *}$ & 0.9931 & 1.181 & $5.15[0.23]^{\mathrm{N} S}$ \\
\hline & Hildreth_I & $-3.66 \mathrm{e} 9(6.79 \mathrm{e} 8)$ & $365343(67730.3)$ & & & $1645012]^{N S}$ \\
\hline & Hildreth-Lu & $5.38^{* * *}$ & $5.394^{* * *}$ & 0.9934 & $1.8 / 4$ & $16.4[0.12]^{150}$ \\
\hline & & $-6852.30(2189.45)$ & $598.28(71.89)$ & & & \\
\hline & OLS & $3.13^{* * *}$ & $8.32^{* * *}$ & 0.5807 & 0.388 & $16.7[7.8 \mathrm{e}-4]$ \\
\hline & Cochrane- & $-9066.95(7575.42)$ & $638.36(220.70)$ & 08527 & 1065 & $1423[01210$ \\
\hline Pakistan & Orcutt & $1.197^{\mathrm{NS}}$ & $2.89^{* * *}$ & 0.8521 & 1.063 & $14.25[0.12]^{-1}$ \\
\hline Pakistan & Prais- & $-4671.47(5628.62)$ & $522.79(177.54)$ & 08526 & 1061 & $3050[0082]^{*}$ \\
\hline & Winsten & $0.829^{\mathrm{NS}}$ & $2.94^{* * *}$ & 0.8526 & 1.061 & $30.50[0.082]$ \\
\hline & Hildreth-L & $-9066.95(7575.42)$ & $638.36(220.70)$ & 08527 & 1065 & $2296[023020$ \\
\hline & Hildreth-Lu & $1.197^{\mathrm{NS}}$ & $2.89^{* * *}$ & 0.8521 & 1.065 & $22.90[0.22]^{100}$ \\
\hline & & $-77.34(300.47)$ & $175.02(9.866)$ & & & \\
\hline & OLS & $0.25^{\mathrm{NS}}$ & $17.74^{* * *}$ & 0.8628 & 0.759 & $5.72[0.220]^{\mathrm{ND}}$ \\
\hline & Cochrane- & $-230.41(667.18)$ & $177.53(20.74)$ & 09136 & 1882 & $2658\left[00466^{* * *}\right.$ \\
\hline Thailand & Orcutt & $0.34^{\mathrm{NS}}$ & $8.55^{* * *}$ & 0.9130 & 1.882 & $20.58[0.040]$ \\
\hline 1manamu & Prais- & $94.11(576.59)$ & $168.59(18.64)$ & 0.9148 & 1866 & $136[0.8887 \mathrm{NS}$ \\
\hline & Winsten & $0.163^{\mathrm{NS}}$ & $9.04^{* * *}$ & 0.9148 & 1.866 & $1.150[0.888]^{100}$ \\
\hline & Hildreth-L & $-230.41(667.18)$ & $177.53(20.74)$ & 0.9136 & 1882 & $0333[0.953]^{N S S}$ \\
\hline & Hildreth-Lu & $0.345^{\mathrm{NS}}$ & $8.55^{* * *}$ & 0.9136 & 1.882 & $0.353[0.953]^{100}$ \\
\hline & & $125.95(17.65)$ & $2.618(0.579)$ & & & $020207^{* *}$ \\
\hline & OLS & $7.13^{* * *}$ & $4.517^{* * *}$ & 0.2898 & 0.5612 & $46.16[0.020]$ \\
\hline & Cochrane- & $130.34(49.11)$ & $2.539(1.487)$ & 0.6480 & 1848 & $2285[06837 \mathrm{NS}$ \\
\hline USA & Orcutt & $2.65^{* *}$ & $1.707^{*}$ & 0.0400 & 1.040 & $2.205[0.003]$ \\
\hline UDA & Prais- & $121.46(38.91)$ & $2.778(1.247)$ & 0.6571 & 1846 & $106450742]^{N S}$ \\
\hline & Winsten & $3.12^{* * *}$ & $2.22^{* *}$ & $0.65 / 1$ & 1.846 & $1.964[0.142]^{50}$ \\
\hline & Hildreth_I & $130.34(49.11)$ & $2.539(1.487)$ & 0.6480 & 1848 & $2285[0.683]^{\mathrm{NS}}$ \\
\hline & Hildreth-Lu & $2.65^{* *}$ & $1.707^{*}$ & 0.6480 & 1.848 & $2.285[0.683]^{100}$ \\
\hline & OI S & $3992.65(699.74)$ & $-22.77(22.97)$ & 09823 & 0.452 & $214[262 \mathrm{e}-4]^{* * *}$ \\
\hline & OLS & $5.706^{* * *}$ & $0.991^{\mathrm{NS}}$ & 0.9823 & 0.452 & $21.4[2.02 \mathrm{e}-4]$ \\
\hline & Cochrane- & $4899.26(2117.20)$ & $-43.33(63.018)$ & 0.6072 & 1.808 & $0.105[0.745]^{\mathrm{NS}}$ \\
\hline China & Orcutt & $2.314^{* *}$ & $0.687^{\mathrm{NS}}$ & $0.00 / 2$ & 1.808 & $0.100[0.145]^{-10}$ \\
\hline & Prais- & $3300.28(1678.09)$ & $-0.6914(53.35)$ & & $178-2,2$ & 01 \\
\hline & Winsten & $1.967^{*}$ & $0.012^{\mathrm{NS}}$ & 036 & $1 . / 86$ & $0.111[0.138]^{\operatorname{vis}}$ \\
\hline & Hildreth-L & $4899.26(2117.20)$ & $-43.33(63.01)$ & 0.6072 & 1808 & $0105[0-$ \\
\hline & Harem-Lu & $2.31^{* *}$ & $0.68^{\mathrm{NS}}$ & $0.00 / 2$ & 1.000 & $0.105[0.14]$ \\
\hline
\end{tabular}

***: Means significant at 1\%,**: Means significant at 5\%, *: Means significant at $10 \%$, NS: Non-significant, Values in ( ) and [ ] are standard error and probability value respectively 


\subsection{Lag selection criteria}

To have a parsimonious result, the lag selection criterion was estimated to give an insight into the appropriate lag number to be included in the analysis. Two VAR lag selection criteria viz. Akaike information criterion (AIC) and HannanQuinn information criterion (HIC) favored lag six (6) against the Schwarz Bayesian information criterion (SBIC) that settled for lag one (1) as evident by the asterisk sign against their respective coefficients (Table 3). Since the former selection criteria have a higher lag order, thus lag six was chosen as the best lag length for truncation to be included in the further analysis.

Table 3. Lag selection criteria

\begin{tabular}{cccc}
\hline $\operatorname{Lag}(\mathrm{s})$ & AIC & BIC & HQC \\
\hline 1 & -1.9528 & $-0.5217^{*}$ & -1.4167 \\
2 & -2.2141 & 0.6481 & -1.1418 \\
3 & -2.4740 & 1.8192 & -0.8657 \\
4 & -2.4075 & 3.3169 & -0.2631 \\
5 & -4.0144 & 3.1410 & -1.3339 \\
6 & $-6.2992^{*}$ & 2.2874 & $-3.0826^{*}$ \\
\hline
\end{tabular}

*: Denote lag length selected by a criterion, AIC: Akaike information criterion, BIC: Schwarz Bayesian information criterion, HQC: HannanQuinn information criterion

\subsection{Unit root tests}

The unit test results of ADF and Kwiatkowski, Phillips, Schmidt, and Shin (KPSS) unit root tests showed all the transformed logarithm price series to have trend at the level as indicated by their respective tau-statistics which were not different from zero at the 5\% probability level (Table 4 ). However, the KPSS test results showed the price series of the USA and China not to have a trend at level as evident by their respective tau-statistics which were within the acceptable margin of 5\% probability. Furthermore, after differencing once, all the price series showed the absence of unit root as shown by their respective tau-statistics which were within the plausible margin of 5\% degree of freedom.

Because of the mismatch between the KPSS test which showed different order of integration and the ADF test which revealed the same order of integration $[\mathrm{I}(1)]$, this cast doubt on the efficiency and consistency of the stationarity of the price series for the co-integration test. Besides, given that $\mathrm{ADF}$ unit root has some weakness, its results need to be verified for reliability as wrong price forecast will have immeasurable negative consequences on any economy i.e. it portends a greater danger to an economy especially developing economies whose resilience to shock is weak. The underlying distribution theories of the ADF test assumed an independent and constant variance for the residuals, which may not be true for many time-series data. Also, the ADF test tends to lose its power to test for stationarity if the length of lag truncation is too large, and if there is a presence of a structural break in the data. Therefore, to have parsimonious results, a robust unit root test viz. Augmented Dickey-Fuller Generalized Least Squares (ADF-GLS) which overcomes these shortcomings was used to verify the consistency of the ADF and to address the problem of the divisionary state of integration between ADF and KPSS tests. The ADF-GLS unit root tests showed all the price series to be nonstationary at the level as indicated by their respective tau-statistics which were greater than the $\mathrm{t}$-critical value at a $5 \%$ significance level. But after the first difference, all the price series became stationary as evident by their respective taustatistics which were less than the tau-critical value at the $5 \%$ probability level. Thus, it can be inferred that the price series are integrated of the same order: integrated of order 1, i.e. [I(1)]. Given that all the price series are integrated of the same order, there is the tendency of them meandering together in the long-run, thus the need to conduct a test of co-integration for verification of price transmission. Despite specification for grading and standardization by WTO, comparable varieties, or grades of rice across the markets is likely. It can be assumed that price variability may be caused by both spatial effects and differences in grades. However, the VAR model concentrates more on the symmetric effect rather than the asymmetric effect.

Table 4. Unit root tests

\begin{tabular}{lllll}
\hline Markets & Stage & ADF & KPSS & ADF-GLS \\
\hline \multirow{2}{*}{ Cambodia } & Level & $-2.214^{\text {ns }}$ & $0.814^{\text {ns }}$ & $-1.166^{\text {ns }}$ \\
& $1^{\text {st }} \Delta$ & $-5.644^{\text {st }}$ & $0.234^{\text {st }}$ & $-3.307^{\text {st }}$ \\
\hline \multirow{2}{*}{ India } & Level & $-2.379^{\text {ns }}$ & $0.838^{\text {ns }}$ & $-2.383^{\text {ns }}$ \\
& $1^{\text {st }} \Delta$ & $-7.766^{\text {st }}$ & $0.102^{\text {st }}$ & $-4.890^{\text {st }}$ \\
\hline \multirow{2}{*}{ Pakistan } & Level & $-0.867^{\text {ns }}$ & $0.838^{\text {ns }}$ & $-2.298^{\text {ns }}$ \\
& $1^{\text {st }} \Delta$ & $-5.770^{\text {st }}$ & $0.198^{\text {st }}$ & $-4.632^{\text {st }}$ \\
\multirow{2}{*}{ Thailand } & Level & $-1.344^{\text {ns }}$ & $0.805^{\text {ns }}$ & $-2.873^{\text {ns }}$ \\
& $1^{\text {st }} \Delta$ & $-6.232^{\text {st }}$ & $0.124^{\text {st }}$ & $-5.948^{\text {st }}$ \\
\hline \multirow{2}{*}{ USA } & Level & $-2.573^{\text {ns }}$ & $0.371^{\text {ns }}$ & $-2.940^{\text {ns }}$ \\
& $1^{\text {st }} \Delta$ & $-7.732^{\text {st }}$ & $0.068^{\text {st }}$ & $-7.770^{\text {st }}$ \\
\hline \multirow{2}{*}{ China } & Level & $-2.693^{\text {ns }}$ & $0.136^{\text {ns }}$ & $-2.466^{\text {ns }}$ \\
& $1^{\text {st }} \Delta$ & $-6.584^{\text {st }}$ & $0.120^{\text {st }}$ & $-6.659^{\text {st }}$ \\
\hline
\end{tabular}

$\mathrm{ADF}$, ADF-GLS, and KPSS tau critical levels at $5 \%$ probability are 3.03 and 0.149 respectively, ns: Non-significant, st: Non-stationary, $\Delta$ : stationary and first difference respectively

\subsection{The extent of market integration}

The bivariate co-integration results of the Engle and Granger test showed the Pakistan market to have a one-way causal co-integration with Cambodia and India markets; and two-way co-integration causation with Thailand market as indicated by their respective tau-statistics which 
were lower than the critical values at 5\% significance level (Table 5). However, the USA market is found to be co-integrated with the Pakistan market as indicated by its tau-statistics which is within the acceptable margin of $5 \%$ probability level. Thailand, USA, and China markets each have one-way causal integration with Cambodia and India markets as evidenced by the significance of their respective coefficients which were within the acceptable margin of 5\% degree of freedom. This showed that the markets to some extent are integrated into the international rice market. Generally, only eleven markets out of the thirty relationships are co-integrated, which revealed a very low level of integration among the major rice exporting markets in the world. Because of the inability of the Engle and Granger test to test for multiple co-integration, Johansen multivariate co-integration test was applied to determine the long-run price association among the selected markets.
Within the plausible margin of 5\% probability level, the multivariate co-integration results showed that out of the six markets, the trace and max tests indicate the presence of co-integration among three and two markets respectively (Table 6 ). This is evident from their respective test values which were different from zero at a $5 \%$ probability level. Given the fact that the max test is more powerful than the trace test (a weaker tool in comparison to the former), it may be argued that at least two co-integration vectors exist along with, at best, four common stochastic trends among the selected six major exporting rice markets in the world. Thus, it can be inferred that there is weak interconnectivity in the prices of these markets despite that they move together in the long-run. The long-run price association of the selected markets is weak as price transmission among them tends to be poor. This revealed the effect of spatiality in creating an asymmetric situation, thus affecting the rice prices of the selected markets in the international market.

Table 5. Engle and Granger tests for co-integration

\begin{tabular}{lccccrr}
\hline Markets & Cambodia & India & Pakistan & Thailand & USA & China \\
\hline Cambodia & & -2.500 & -2.718 & -1.459 & -1.995 & -1.482 \\
India & -1.587 & & -2.164 & -2.002 & -1.796 & -2.522 \\
Pakistan & $-4.368^{*}$ & $-5.617^{*}$ & & $-4.331^{*}$ & -2.990 & -2.464 \\
Thailand & $-3.495^{*}$ & $-3.541^{*}$ & $-3.437^{*}$ & & -1.664 & -1.327 \\
USA & $-3.609^{*}$ & $-3.751^{*}$ & $-3.373^{*}$ & -2.812 & -2.450 \\
China & $-3.036^{*}$ & $-3.497^{*}$ & -2.821 & -2.894 & -2.776 & \\
\hline
\end{tabular}

$\mathrm{ADF}$ tau critical level at $5 \%$ probability is $-3.03, *$ : Indicates significance at $5 \%$

Table 6. Multivariate horizontal-wise co-integration

\begin{tabular}{cccccc}
\hline Rank & Eigen value & Trace test & P-value & Lmax test & P-value \\
\hline 0 & 0.91088 & 254.93 & 0.0000 & 111.22 & 0.0000 \\
1 & 0.78389 & 143.72 & 0.0000 & 70.471 & 0.0000 \\
2 & 0.63480 & 73.247 & 0.0000 & 46.337 & 0.0000 \\
3 & 0.30833 & $26.910^{* *}$ & 0.0216 & 16.958 & 0.0649 \\
4 & 0.17839 & 9.9525 & 0.1212 & 9.0385 & 0.1196 \\
5 & 0.01967 & 0.9140 & 0.3939 & 0.9140 & 0.3899 \\
\hline
\end{tabular}

**: Denotes rejection of the null hypothesis at a 5 percent level of significance

Even though the markets are integrated, the presence of four common stochastic trends indicates the absence of pair-wise co-integration of prices, implying that the LOP does not hold. In other words, two market prices being expressed with respect to four markets means that the prices in the six markets are poorly co-integrated as the LOP did not hold. Given that all these markets are weakly co-integrated, it can be suggested that they are likely to converge to long-run equilibrium i.e. establish long-run equilibrium in the sense that the international rice market system is non-stationary in four directions and stationary in two directions.
Therefore, the inter-market price linkages confirmed that transportation costs have a significant impact on determining the degree of market integration in the global international rice market.

Generally, both the co-integration tests viz. Engle and Granger, and Johansen methods indicate that the international rice markets are weakly integrated in the long-run as only two out of six markets established a co-integration. Also, it indicates the presence of four common stochastic trends; hence four independent markets existed among the six markets. 


\subsection{Degree of market integration}

The presence of co-integration shows the existence among the co-integrated variables of long-run price equilibrium (Table 7). The diagnostic tests showed the VECM model to be suitable for the specified equation as evident by the Ljung-Box Q and Langrage multiplier test statistics respectively for the serial correlation and $\mathrm{ARCH}$ effect that were not different from zero at $10 \%$ probability level. Thus, indicating the absence of autocorrelation and Arch effect for all the six estimated VECMs. However, the residual was not normally skewed as evident by the DoornikHansen test statistic which is within the plausible margin of a $10 \%$ probability level. Non-normality has been reported not to be a serious problem as data in their natural form in most cases are not normally distributed (Sadiq et al., 2017, 2020a). Thus, the model is reliable for prediction with certainty, efficiency, and consistency.

Table 7. Degree of market integration

\begin{tabular}{|c|c|c|c|}
\hline Variable & $\Delta$ Cambodia & $\Delta$ India & $\Delta$ Pakistan \\
\hline Cambodiat-1 & $0.2098(0.216)[0.971]^{\mathrm{NS}}$ & $0.4246(0.0976)[4.348]^{* * *}$ & $0.1282(0.2349)[0.545]^{\mathrm{NS}}$ \\
\hline Cambodiat-2 & $0.5043(0.2087)[2.416]^{* *}$ & $0.3866(0.0943)[4.097]^{* * *}$ & $-0.2381(0.2271)[1.049]^{\mathrm{NS}}$ \\
\hline Cambodiat-3 & $0.7272(0.2327)[3.124]^{* * *}$ & $0.1693(0.1052)[1.609]^{\mathrm{NS}}$ & $0.0723(0.2532)[0.285]^{\mathrm{NS}}$ \\
\hline Cambodiat 4 & $0.3604(0.1824)[1.97]^{*}$ & $-0.1342(0.0824)[1.628]^{\mathrm{NS}}$ & $0.2397(0.1984)[1.208]^{\mathrm{NS}}$ \\
\hline Cambodiat -5 & $0.1876(0.1496)[1.254]^{\mathrm{NS}}$ & $-0.2696(0.0676)[3.986]^{* * *}$ & $0.1976(0.1628)[1.214]^{\mathrm{NS}}$ \\
\hline Indiat -1 & $-0.1119(0.3694)[0.302]^{\mathrm{NS}}$ & $-0.4936(0.1670)[2.956]^{* *}$ & $-0.6126(0.4019)[1.524]^{\mathrm{NS}}$ \\
\hline Indiat-2 & $0.3638(0.3040)[1.197]^{\mathrm{NS}}$ & $-0.2786(0.1374)[2.027]^{*}$ & $-0.6887(0.3308)[2.082]^{*}$ \\
\hline Indiat -3 & $0.1925(0.3064)[0.628]^{\mathrm{NS}}$ & $-0.3097(0.1385)[2.236]^{* *}$ & $-0.6791(0.3333)[2.037]^{*}$ \\
\hline Indiat-4 & $-0.1995(0.2545)[0.784]^{\mathrm{NS}}$ & $-0.2481(0.1150)[2.157]^{*}$ & $-0.1513(0.2769)[0.546]^{\mathrm{NS}}$ \\
\hline Indiat-5 & $-0.5969(0.2474)[2.413]^{* *}$ & $0.0016(0.1118)[0.014]^{\mathrm{NS}}$ & $-0.3703(0.2691)[1.376]^{\mathrm{NS}}$ \\
\hline Pakistant-1 & $-0.5360(0.4485)[1.195]^{\mathrm{NS}}$ & $-0.6396(0.2027)[3.155]^{* * *}$ & $0.6520(0.4879)[1.336]^{\mathrm{NS}}$ \\
\hline Pakistant-2 $_{\mathrm{t}}$ & $-0.4746(0.3868)[1.227]^{\mathrm{NS}}$ & $-0.5048(0.1748)[2.887]^{* *}$ & $0.5524(0.4208)[1.313]^{\mathrm{NS}}$ \\
\hline Pakistan $_{\mathrm{t}-3}$ & $-0.5837(0.3931)[1.485]^{\mathrm{NS}}$ & $-0.7731(0.1777)[4.350]^{* * *}$ & $0.0537(0.4277)[0.125]^{\mathrm{NS}}$ \\
\hline Pakistan $_{\mathrm{t}-4}$ & $-0.5158(0.4418)[1.167]^{\mathrm{NS}}$ & $-0.6561(0.1997)[3.285]^{* * *}$ & $0.1511(0.4806)[0.314]^{\mathrm{NS}}$ \\
\hline Pakistan $_{\mathrm{t}-5}$ & $-0.3125(0.4436)[0.704]^{\mathrm{NS}}$ & $-0.4759(0.2005)[2.373]^{* *}$ & $-0.2290(0.4826)[0.474]^{\mathrm{NS}}$ \\
\hline Thailandt-1 & $-0.4210(0.4736)[0.888]^{\mathrm{NS}}$ & $-0.0277(0.2141)[0.129]^{\mathrm{NS}}$ & $-1.1681(0.5152)[2.267]^{* *}$ \\
\hline Thailandt-2 & $-0.5278(0.1804)[2.926]^{* *}$ & $0.1537(0.0815)[1.885]^{*}$ & $-0.2956(0.1962)[1.506]^{\mathrm{NS}}$ \\
\hline Tthailand $\mathrm{t}_{\mathrm{t} 3}$ & $-0.3109(0.2253)[1.380]^{\mathrm{NS}}$ & $0.1830(0.1018)[1.797]^{*}$ & $-0.2324(0.2451)[0.948]^{\mathrm{NS}}$ \\
\hline Thailandt-4 & $0.0794(0.1854)[0.428]^{\mathrm{NS}}$ & $0.1795(0.0838)[2.142]^{*}$ & $-0.5125(0.2016)[2.541]^{* *}$ \\
\hline Thailandt-5 & $-0.1480(0.2039)[0.725]^{\mathrm{NS}}$ & $0.0487(0.0922)[0.528]^{\mathrm{NS}}$ & $-0.0106(0.2219)[0.0481]^{\mathrm{NS}}$ \\
\hline $\mathrm{USA}_{\mathrm{t}-1}$ & $0.1544(0.2019)[0.764]^{\mathrm{NS}}$ & $-0.1114(0.0912)[1.221]^{\mathrm{NS}}$ & $0.5110(0.2196)[2.327]^{* *}$ \\
\hline $\mathrm{USA}_{\mathrm{t}-2}$ & $0.1197(0.1848)[0.647]^{\mathrm{NS}}$ & $-0.0930(0.0835)[1.113]^{\mathrm{NS}}$ & $0.2593(0.2010)[1.290]^{\mathrm{NS}}$ \\
\hline $\mathrm{USA}_{\mathrm{t}-3}$ & $-0.1244(0.1729)[0.719]^{\mathrm{NS}}$ & $-0.0674(0.0781)[0.863]^{\mathrm{NS}}$ & $0.0756(0.1881)[0.402]^{\mathrm{NS}}$ \\
\hline $\mathrm{USA}_{\mathrm{t}-4}$ & $-0.0241(0.1434)[0.168]^{\mathrm{NS}}$ & $0.3017(0.0648)[4.655]^{* * *}$ & $0.2927(0.1559)[1.877]^{*}$ \\
\hline USAt-5 & $0.0739(0.1811)[0.408]^{\mathrm{NS}}$ & $0.0987(0.0818)[1.206]^{\mathrm{NS}}$ & $0.0971(0.1971)[0.492]^{\mathrm{NS}}$ \\
\hline Chinat-1 & $0.1066(0.0998)[1.068]^{\mathrm{NS}}$ & $0.0907(0.0451)[2.011]^{\mathrm{NS}}$ & $-0.0112(0.1086)[0.103]^{\mathrm{NS}}$ \\
\hline Chinat-2 & $-0.1655(0.1023)[1.617]^{\mathrm{NS}}$ & $0.1391(0.0462)[3.006]^{\mathrm{NS}}$ & $0.0809(0.1113)[0.726]^{\mathrm{NS}}$ \\
\hline Chinat-3 & $0.0641(0.0978)[0.656]^{\mathrm{NS}}$ & $0.1221(0.0442)[2.762]^{* *}$ & $-0.0095(0.1064)[0.089]^{\mathrm{NS}}$ \\
\hline Chinat-4 & $0.1056(0.0895)[1.180]^{\mathrm{NS}}$ & $0.1054(0.0404)[2.605]^{* *}$ & $-0.1078(0.0974)[1.107]^{\mathrm{NS}}$ \\
\hline Chinat-5 & $0.0576(0.0744)[0.774]^{\mathrm{NS}}$ & $-0.0131(0.0336)[0.390]^{\mathrm{NS}}$ & $-0.0537(0.0809)[0.663]^{\mathrm{NS}}$ \\
\hline ECt-1 & $-0.5845(0.2163)[2.701]^{* *}$ & $-0.3095(0.0978)[3.165]^{* * *}$ & $-0.2059(0.2353)[0.875]^{\mathrm{NS}}$ \\
\hline ECt-2 & $-0.2689(0.3152)[0.853]^{\mathrm{NS}}$ & $-0.5175(0.1425)[3.632]^{* * *}$ & $0.8560(0.3429)[2.496]^{* *}$ \\
\hline ECt-3 & $0.6791(0.4659)[1.458]^{\mathrm{NS}}$ & $0.7610(0.2106)[3.613]^{\mathrm{NS}}$ & $-0.9141(0.5068)[1.804]^{*}$ \\
\hline $\mathrm{R}^{2}$ & 0.9408 & 0.9673 & 0.8817 \\
\hline D-W stat & 2.106 & 2.2116 & 2.217 \\
\hline Autocorrelation $\left(\mathrm{Chi}^{2}\right)$ & $0.193\{0.66\}^{\mathrm{NS}}$ & $0.593\{0.441\}^{\mathrm{NS}}$ & $0.855\{0.355\}^{\mathrm{NS}}$ \\
\hline Arch effect (LM test) & $1.924\{0.926\}^{\mathrm{NS}}$ & $3.542\{0.738\}^{\mathrm{NS}}$ & $5.124\{0.527\}^{\mathrm{NS}}$ \\
\hline Normality $\left(\mathrm{Chi}^{2}\right)$ & $37.44\{0.0002\}^{\text {*** }}$ & & \\
\hline
\end{tabular}

The long-run dynamic measured by the VECM showed negative and significant attractor coefficients for most of the selected markets viz. Cambodian, Indian, Thailand, and USA markets; thus, indicating that prices in these markets tend to converge to long-run equilibrium. Thus, it can be inferred that these markets established a long-run equilibrium. The adjustment speeds for Cambodian, Indian, Thailand, and USA markets are $-0.585,-0.310,-0.455$, and $-1.546 \%$ respectively. This showed that $58.5 \%, 30.9 \%$, $45.4 \%$, and $154.6 \%$ of divergences from the longrun equilibrium with respect to Cambodian, Indian, Thailand, and USA markets are being 
corrected annually. The time required per annum for Cambodian, Indian, Thailand, and USA markets to re-establish equilibrium in the long-run or move from disequilibrium to equilibrium would be $7.02,3.72,5.46$, and 18.55 months, respectively. The process of adjustment is relatively faster in the Indian market and this might be due to lesser transfer and transaction costs which owes to proximity and better infrastructure. However, the process of adjustment was relatively moderate and longer in Thailand and USA markets respectively.

Table 7. (Continued)

\begin{tabular}{|c|c|c|c|}
\hline Variable & $\Delta$ Thailand & $\Delta \mathrm{USA}$ & $\Delta$ China \\
\hline Cambodiat $-1_{1}$ & $0.2862(0.2452)[1.168]^{\mathrm{NS}}$ & $1.1090(0.3470)[3.195]^{* * *}$ & $-0.2084(0.9693)[0.215]^{\mathrm{NS}}$ \\
\hline Cambodiat-2 & $0.5090(0.2369)[2.148]^{* *}$ & $1.0744(0.3354)[3.203]^{* * *}$ & $0.6135(0.9368)[0.654]^{\mathrm{NS}}$ \\
\hline Cambodiat-3 & $0.5035(0.2642)[1.906]^{*}$ & $1.1535(0.3740)[3.084]^{* * *}$ & $0.2255(1.0446)[0.215]^{\mathrm{NS}}$ \\
\hline Cambodiat -4 & $0.2581(0.2070)[1.247]^{\mathrm{NS}}$ & $0.7380(0.2930)[2.518]^{* *}$ & $-0.2675(0.8185)[0.326]^{\mathrm{NS}}$ \\
\hline Cambodiat -5 & $0.0822(0.1698)[0.484]^{\mathrm{NS}}$ & $0.4765(0.2404)[1.982]^{*}$ & $-0.5791(0.6715)[0.862]^{\mathrm{NS}}$ \\
\hline Indiat-1 & $0.5229(0.4194)[1.247]^{\mathrm{NS}}$ & $1.3551(0.5936)[2.283]^{* *}$ & $-1.4995(1.6580)[0.904]^{\mathrm{NS}}$ \\
\hline Indiat-2 & $0.0983(0.3451)[0.285]^{\mathrm{NS}}$ & $0.6150(0.4886)[1.259]^{\mathrm{NS}}$ & $-0.7564(1.3645)[0.554]^{\mathrm{NS}}$ \\
\hline Indiat-3 & $0.5335(0.3478)[1.534]^{\mathrm{NS}}$ & $0.8749(0.4923)[1.777]^{\mathrm{NS}}$ & $-0.4006(1.3751)[0.291]^{\mathrm{NS}}$ \\
\hline Indiat-4 & $-0.1819(0.2889)[0.629]^{\mathrm{NS}}$ & $0.8153(0.4089)[1.994]^{*}$ & $-1.2154(1.1422)[1.064]^{\mathrm{NS}}$ \\
\hline Indiat-5 & $0.0924(0.2808)[0.329]^{\mathrm{NS}}$ & $0.4323(0.3975)[1.088]^{\mathrm{NS}}$ & $-0.5958(1.1101)[0.5367]^{\mathrm{NS}}$ \\
\hline Pakistan $_{\mathrm{t}-1}$ & $-0.6146(0.5091)[1.207]^{\mathrm{NS}}$ & $-2.4247(0.7206)[3.365]^{* * *}$ & $-0.3749(2.0126)[0.186]^{\mathrm{NS}}$ \\
\hline Pakistant $_{\mathrm{t}-2}$ & $-0.7776(0.4391)[1.771]^{\mathrm{NS}}$ & $-2.8585(0.6216)[4.598]^{* * *}$ & $0.3955(1.7361)[0.227]^{\mathrm{NS}}$ \\
\hline Pakistant-3 & $-0.4075(0.4463)[0.913]^{\mathrm{NS}}$ & $-1.9998(0.6317)[3.166]^{* * *}$ & $1.5340(1.7643)[0.869]^{\mathrm{NS}}$ \\
\hline Pakistan $_{\mathrm{t}-4}$ & $-1.0694(0.5015)[2.132]^{*}$ & $-2.5162(0.7099)[3.544]^{* * *}$ & $-1.1339(1.9828)[0.571]^{\mathrm{NS}}$ \\
\hline Pakistant-5 & $-0.2932(0.5036)[0.582]^{\mathrm{NS}}$ & $-2.5743(0.7128)[3.611]^{* * *}$ & $-0.8904(1.9908)[0.447]^{\mathrm{NS}}$ \\
\hline Thailand $_{\mathrm{t}-1}$ & $-0.2621(0.5376)[0.487]^{\mathrm{NS}}$ & $-0.9552(0.7610)[1.255]^{\mathrm{NS}}$ & $0.2110(2.1255)[0.099]^{\mathrm{NS}}$ \\
\hline Thailand $_{\mathrm{t}-2}$ & $-0.5614(0.2047)[2.742]^{* *}$ & $-0.3222(0.2898)[1.112]^{\mathrm{NS}}$ & $0.1320(0.8095)[0.163]^{\mathrm{NS}}$ \\
\hline Tthailand $_{\mathrm{t}-3}$ & $-0.2498(0.2557)[0.977]^{\mathrm{NS}}$ & $-0.5301(0.3620)[1.464]^{\mathrm{NS}}$ & $-0.9533(1.0111)[0.942]^{\mathrm{NS}}$ \\
\hline Thailand $\mathrm{t}_{-4}$ & $0.0914(0.2104)[0.434]^{\mathrm{NS}}$ & $0.0163(0.2979)[0.054]^{\mathrm{NS}}$ & $0.0161(0.8319)[0.0194]^{\mathrm{NS}}$ \\
\hline Thailand $\mathrm{t}_{-5}$ & $0.0381(0.2315)[0.164]^{\mathrm{NS}}$ & $0.3368(0.3277)[1.028]^{\mathrm{NS}}$ & $-0.0311(0.9153)[0.0340]^{\mathrm{NS}}$ \\
\hline $\mathrm{USA}_{\mathrm{t}-1}$ & $0.0647(0.2292)[0.282]^{\mathrm{NS}}$ & $-0.6914(0.3244)[2.131]^{*}$ & $0.0753(0.9060)[0.083]^{\mathrm{NS}}$ \\
\hline $\mathrm{USA}_{\mathrm{t}-2}$ & $-0.3501(0.2098)[1.669]^{\mathrm{NS}}$ & $-0.7820(0.2969)[2.633]^{* *}$ & $0.0693(0.8294)[0.0835]^{\mathrm{NS}}$ \\
\hline $\mathrm{USA}_{\mathrm{t}-3}$ & $-0.1701(0.1963)[0.866]^{\mathrm{NS}}$ & $-0.6347(0.2779)[2.284]^{* *}$ & $0.3137(0.7762)[0.404]^{\mathrm{NS}}$ \\
\hline $\mathrm{USA}_{\mathrm{t}-4}$ & $-0.1014(0.1627)[0.623]^{\mathrm{NS}}$ & $-0.1918(0.2304)[0.832]^{\mathrm{NS}}$ & $0.3627(0.6434)[0.563]^{\mathrm{NS}}$ \\
\hline USAt-5 & $-0.1852(0.2056)[0.900]^{\mathrm{NS}}$ & $-0.1380(0.2911)[0.474]^{\mathrm{NS}}$ & $1.2227(0.8130)[1.504]^{\mathrm{NS}}$ \\
\hline Chinat-1 & $0.2485(0.1133)[2.192]^{* *}$ & $0.6476(0.1604)[4.036]^{* * *}$ & $0.0253(0.4482)[0.056]^{\mathrm{NS}}$ \\
\hline Chinat-2 & $0.1985(0.1162)[1.708]^{\mathrm{NS}}$ & $0.5406(0.1645)[3.287]^{* * *}$ & $-0.3339(0.4594)[0.726]^{\mathrm{NS}}$ \\
\hline Chinat-3 & $0.1729(0.1110)[1.558]^{\mathrm{NS}}$ & $0.4252(0.1571)[2.706]^{* *}$ & $0.0252(0.43892)[0.0576]^{\mathrm{NS}}$ \\
\hline Chinat-4 & $0.1612(0.1016)[1.586]^{\mathrm{NS}}$ & $0.3061(0.1438)[2.128]^{*}$ & $0.0469(0.4018)[0.116]^{\mathrm{NS}}$ \\
\hline Chinat-5 & $0.0812(0.0845)[0.961]^{\mathrm{NS}}$ & $0.2503(0.1196)[2.093]^{*}$ & $-0.0109(0.3340)[0.0327]^{\mathrm{NS}}$ \\
\hline ECt-1 & $-0.4546(0.2456)[1.851]^{*}$ & $-1.5462(0.3476)[4.447]^{* * *}$ & $0.4984(0.9710)[0.513]^{\mathrm{NS}}$ \\
\hline ECt-2 & $-0.4418(0.3578)[1.235]^{\mathrm{NS}}$ & $-1.7446(0.5065)[3.444]^{* * *}$ & $0.2769(1.4147)[0.195]^{\mathrm{NS}}$ \\
\hline ECt-3 & $0.8098(0.5288)[1.531]^{\mathrm{NS}}$ & $3.0376(0.7486)[4.058]^{* * *}$ & $-0.7273(2.0908)[0.347]^{\mathrm{NS}}$ \\
\hline $\mathrm{R}^{2}$ & 0.8489 & 0.8615 & 0.6595 \\
\hline D-W stat & 2.1492 & 2.710 & 1.622 \\
\hline Autocorrelation $\left(\mathrm{Chi}^{2}\right)$ & $0.298\{0.585\}^{\mathrm{NS}}$ & $6.215\{0.127\}^{\mathrm{NS}}$ & $1.666\{0.197\}^{\mathrm{NS}}$ \\
\hline Arch effect (LM test) & $2.360\{0.883\}^{\mathrm{NS}}$ & $7.399\{0.285\}^{\mathrm{NS}}$ & $3.652\{0.723\}^{\mathrm{NS}}$ \\
\hline Normality $\left(\mathrm{Chi}^{2}\right)$ & & $37.44\{0.0002\}^{* * *}$ & \\
\hline
\end{tabular}

Furthermore, the prices of rice in these markets are stable in the long-run and any deviation in the equilibrium due to exogenous shocks that occur in the short-run is well adjusted. In other words, a price shock that induces price deviation from their respective equilibrium level will induce the traders to respond to the shocks in a way that prices will converge towards their equilibrium level.

The market prices of Pakistan and China did not establish a long-run equilibrium as evident by the non-significant of their respective attractor coefficients at a $10 \%$ degree of freedom, thus implying that they are not stable. However, the factors that might have undermined the degree of market integration and generate discontinuities in the price responses to external shocks may be due to the presence of high transaction costs relative to the price differential of these markets in the international rice market, thus making them autarkic markets. Also, for the Pakistan market, the presence of barriers to entry, risk aversion, and 
information failures may be contributing factors. Some of the characteristics of agricultural production, commercialization and consumption, inadequate transport infrastructure, barriers to entry, and failure to provide information, cause more friction in the arbitration process than conventional market integration models assume.

The existence of menu costs understood as those costs that result from the re-pricing and information process that producers face in the presence of exogenous variations caused discontinuous or asymmetric price responses in Pakistan and USA markets. If the agents perceive variations in the costs of the commodity as temporary, the menu costs might constitute an incentive not to adjust prices even when a change in the product cost has actually occurred.

Empirical evidence showed these stabled markets to have delays in their respective long-run price transmissions as the coefficients of the lagged price differences are different from zero at the $10 \%$ probability level. The effects of lagged prices in the selected markets were positive as well as negative, suggesting that, in the short-run, price shocks were contemporaneously transmitted in these markets but not fully. Therefore, in the shortrun, the market price of Cambodia is transmitted to Indian, Thailand, and USA markets while Thailand's market price is transmitted to Cambodian, Indian, Pakistan, and USA markets. The market price of India is transmitted to Cambodian, Pakistan, and USA markets while the market price of the USA is transmitted to Indian and Pakistan markets. China has its market price being transmitted to Indian and USA markets. However, none of the markets had their price transmitted to China market. Thus, there is a need to enhance the development of market infrastructure, use of information and technology in the transaction of goods, processing, transportation thereby strengthens the linkage and interconnectedness among these markets.

Therefore, except the duo viz. Pakistan and China markets, it can be inferred that the high degree of market integration observed for the remaining markets implies that they are quite competitive and provide little justification for extensive and costly government intervention designed to improve competitiveness for enhanced market efficiency.

\subsection{Price formation process}

Granger causality was determined among the selected market pairs after assessing co-integration between the different rice markets (Table 8). The causality of the granger indicates the direction of price formation between two markets and associated spatial arbitrage, i.e. the commodity's physical movement to change the price difference (Ghafoor et al., 2009). The results showed that the prices of Cambodian, Pakistan, and Thailand markets had a significant influence on the prices of two, five, and one market respectively as evident by the significance of their respective F-statistics at a 5\% probability level. The test showed unidirectional causalities between the market pairs viz. Cambodia-Thailand, and Cambodia-China; Pakistan-Cambodia, Pakistan-India, PakistanThailand, Pakistan-USA and Pakistan-China; and Thailand-India markets. This implies that the price change in the former market in each pair granger causes the price formation in the latter market, while the price change in the latter market is not feedback by the price change in the former market. In other words, it means that the former market in each pair influenced price formation in the latter, whereas the latter market does not influence the price formation of the former market. Thus, it can be concluded that rice prices adjust in markets according to the demand and supply situation in the international market.

Furthermore, it was observed that the market pairs viz. Cambodia-USA, India-USA, IndiaChina, Thailand-USA, and Thailand-China had no direct causality between them. This means that neither price change in the former market in each pair granger causes price formation in the latter market, nor a price change in the latter market granger causes price formation in the former markets. This implies that these market pairs are weakly exogenous to each other i.e. weak exogenity. However, none of the markets was found to be an independent market-strongly exogenous (strong exogenity), i.e. has its price formation been determined by external factors entirely outside the market system.Bidirectional causality where both markets granger causes price formations on each other in a pair was not observed. This may be attributed to asymmetric price responses viz. high transaction costs which result in autarkic market, menu costs: re-pricing and information processes, entry barriers, risk aversions, information failures, and oligopolistic middlemen.

Generally, it can be inferred that Pakistan's market prices had a dominant role in the prices of all the selected rice markets. Out of the thirty relationships, only eight relationships were weakly exogenous with no case of any strong exogeneity or strong endogeneity in the relationships. In line with the Engle and Granger co-integration test, the Granger causality tests also showed that most of 
Table 8. Horizontal pair-wiseranger causality test

\begin{tabular}{|c|c|c|c|c|}
\hline Null hypothesis & $\mathrm{Chi}^{2}$ & $\mathrm{P}<0.05$ & Granger cause & Direction \\
\hline \multirow{2}{*}{$C A M \leftrightarrow I N D I A$} & 8.8473 & 0.182 & No & None \\
\hline & 4.1967 & 0.650 & No & \\
\hline \multirow{2}{*}{$C A M \leftrightarrow P A K$} & 8.1742 & 0.226 & No & Unidirectional \\
\hline & 34.395 & $0.000^{*}$ & Yes & \\
\hline \multirow[b]{2}{*}{$C A M \leftrightarrow T H A I$} & 35.225 & $0.000^{*}$ & Yes & Unidirectional \\
\hline & 5.1737 & 0.522 & No & \\
\hline \multirow{2}{*}{$C A M \leftrightarrow U S A$} & 6.2315 & 0.398 & No & None \\
\hline & 2.8918 & 0.822 & No & \\
\hline \multirow{2}{*}{$C A M \leftrightarrow C H I N A$} & 45.068 & $0.000^{*}$ & Yes & Unidirectional \\
\hline & 4.4917 & 0.610 & No & \\
\hline \multirow{2}{*}{$I N D I A \leftrightarrow P A K$} & 3.3994 & 0.757 & No & Unidirectional \\
\hline & 93.809 & $0.000^{*}$ & Yes & \\
\hline \multirow{2}{*}{$I N D I A \leftrightarrow T H A I$} & 8.492 & 0.204 & No & Unidirectional \\
\hline & 23.667 & $0.001^{*}$ & Yes & \\
\hline \multirow{2}{*}{$I N D I A \leftrightarrow U S A$} & 2.7442 & 0.840 & No & None \\
\hline & 5.368 & 0.498 & No & \\
\hline \multirow{2}{*}{$I N D I A \leftrightarrow C H I N A$} & 3.1962 & 0.376 & No & None \\
\hline & 2.2771 & 0.893 & No & \\
\hline \multirow{2}{*}{$P A K \leftrightarrow T H A I$} & 42.257 & $0.000^{*}$ & Yes & Unidirectional \\
\hline & 2.265 & 0.894 & No & \\
\hline \multirow{2}{*}{$P A K \leftrightarrow U S A$} & 18.405 & $0.005^{*}$ & Yes & Unidirectional \\
\hline & 4.1531 & 0.656 & No & \\
\hline \multirow{2}{*}{$P A K \leftrightarrow C H I N A$} & 15.263 & $0.018^{*}$ & Yes & Unidirectional \\
\hline & 5.5577 & 0.475 & No & \\
\hline \multirow{2}{*}{$T H A I \leftrightarrow U S A$} & 2.7833 & 0.836 & No & None \\
\hline & 3.6922 & 0.718 & No & \\
\hline \multirow{2}{*}{$T H A I \leftrightarrow C H I N A$} & 2.3456 & 0.885 & No & None \\
\hline & 4.3917 & 0.624 & No & \\
\hline \multirow{2}{*}{$U S A \leftrightarrow C H I N A$} & 2.1061 & 0.910 & No & None \\
\hline & 3.2967 & 0.771 & No & \\
\hline$C A M \rightarrow A L L$ & 173.22 & $0.000^{*}$ & Yes & Multidirectional \\
\hline$I N D I A \rightarrow A L L$ & 31.815 & 0.376 & No & None \\
\hline$P A K \rightarrow A L L$ & 232.58 & $0.000^{*}$ & Yes & Multidirectional \\
\hline$T H A I \rightarrow A L L$ & 104.55 & $0.000^{*}$ & Yes & Multidirectional \\
\hline$U S A \rightarrow A L L$ & 16.761 & 0.975 & No & Multidirectional \\
\hline CHINA $\rightarrow$ ALL & 8.2151 & 1.000 & No & None \\
\hline
\end{tabular}

*: Denotes rejection of the $\mathrm{H}_{0}$ at $5 \%$ level of significance, NS: Non-significant, $\rightarrow \leftarrow$ means forward and backward directions respectively

these markets were not integrated and are independent of each other in the long-run.

\subsection{Effect of price shock}

Whereas over time IRFs from a stationary VAR die out, IRFs from a VECM cointegrating do not always die out. The effect of a shock on each of these variables must die out so that the variable can return to its mean since each variable in a stationary VAR has a time-invariant mean and finite, time-invariant variance. In contrast, the integrated order 1 , that is, I(1) variables modeled in a cointegrating VECM are not mean reverting, the unit moduli in the companion matrix imply that the effects of some shocks will not die out over time (Sadiq et al., 2017).

A cursory review of the impulse response functions shows how and to what extent a standard deviation shock in one of the selected markets affects the current as well as the future prices in all the integrated markets over a period of ten years (Figure 1). The graphs showed that an unexpected shock that is local to the Cambodian market will have a permanent effect on China's market and a transitory effect on all the remaining markets inclusive itself. An orthogonalized shock to the average rice price of India will not die out over time in Cambodian, Thailand, USA markets, and its market, while its effect will die out over time in Pakistan and China markets.

Unexpected price shocks that are local to Pakistan's market will have a permanent effect on only the China market and a transitory effect on all the remaining markets inclusive itself. An unexpected shock that is local to the Thailand market will not die out over time in Cambodian, 


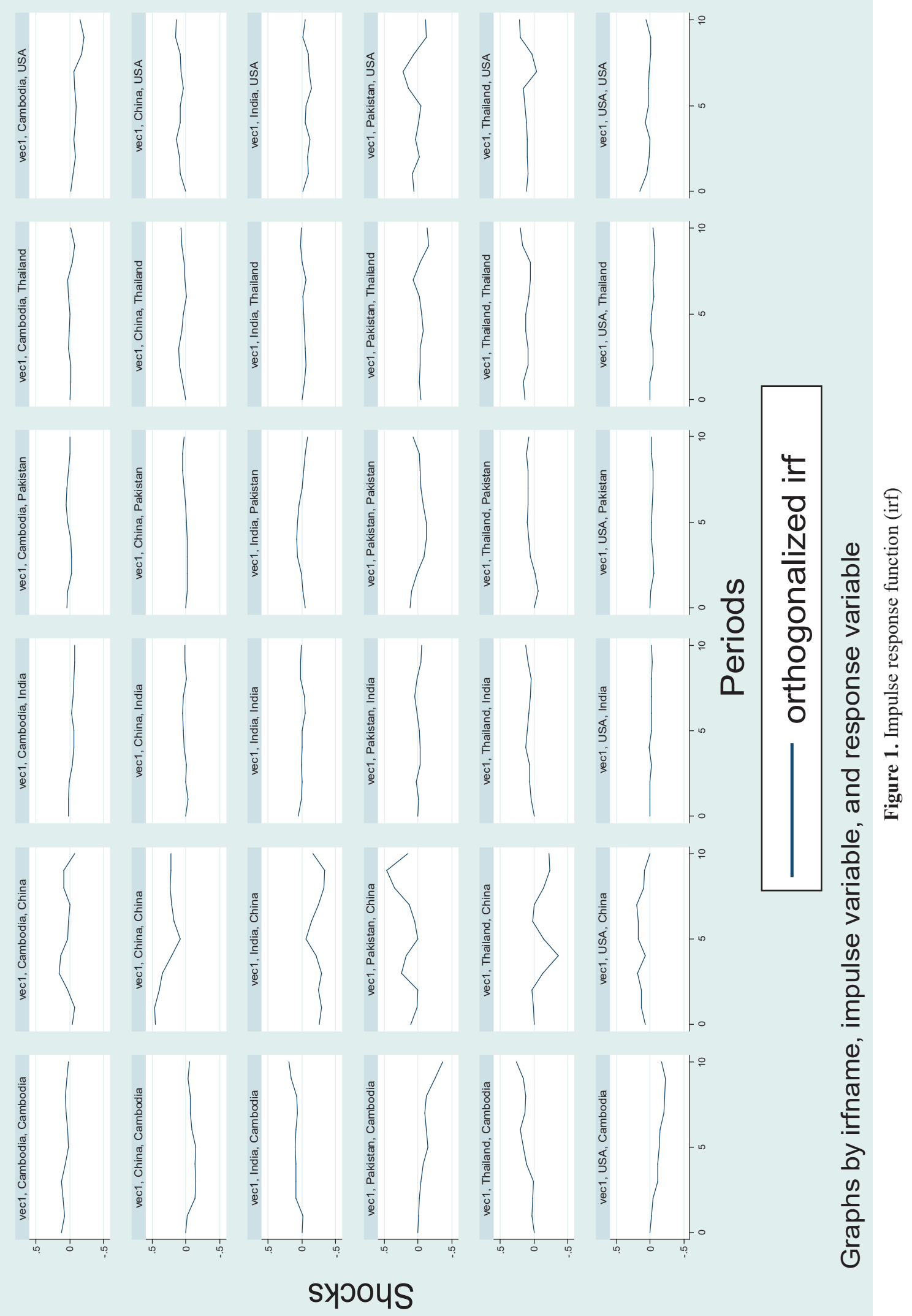


Indian, Pakistan, USA markets, and its market, while it will die out over time in China market. An orthogonalized shock to the average rice price of the USA will have a permanent effect on only the Pakistan market and a transitory effect on all the remaining markets. An unexpected shock that is local to the China market will have a permanent effect on Cambodian, Indian, Pakistan, Thailand, USA markets, and its market. The reason for the transient price shock effect of the China market on all the selected markets may be attributed to its inventory accumulation, thus a source of discontinuity in the adjustment of prices between the markets.

Price fluctuations give inventory holders signals that lead them to accumulate or decrease stocks. The capacity of traders to hold stocks is referred to as the 'leverage effect'. The anticipated rise in the price of the dominant market over the next period is an opportunity for traders to raise their inventory holdings, thereby purchasing large quantities of rice products at present. The rise in local market stocks, however, is driving prices down, so the real rise is not as high as originally predicted. On the contrary, if it were to be predicted that the prevailing market prices would decline, this would be an incentive for traders to reduce their inventory stocks, a reaction that would moderate the severity of the subsequent fall in prices. Given this inventory keeping mechanism, China's market prices will not respond entirely to shifts in the selected market prices.

\subsection{Price forecast}

Through the one-step-ahead forecast, the validity of the predictive power of the best fit VECM was checked, and how closely they could follow the direction of the actual observations (Table 9).

In addition, as indicated by Theil's coefficient of inequality (U) and the RMAPE, respectively within the range of 1 and 5 percent (Table 10), the VECM was found to be accurate for prediction. The VECM can therefore be used with high forecast validity and accuracy for ex-ante forecast, as the predictive error associated with the projected equation is negligible and low in monitoring the actual data (ex-post prediction).

Table 9. One step ahead forecast of prices (\$)

\begin{tabular}{|c|c|c|c|c|c|c|c|c|c|c|c|c|}
\hline \multirow{2}{*}{ Year } & \multicolumn{2}{|c|}{ Cambodia } & \multicolumn{2}{|c|}{ India } & \multicolumn{2}{|c|}{ Pakistan } & \multicolumn{2}{|c|}{ Thailand } & \multicolumn{2}{|c|}{ USA } & \multicolumn{2}{|c|}{ China } \\
\hline & ctual & Pred & tual & & tual & Pred & tual & Pred & tual & & ual & \\
\hline & & & & & & & & & & & & \\
\hline & & & & & & & & & & & & \\
\hline & & & & & & & & & & & & \\
\hline & & & & & & & & & 22 & & & \\
\hline 017 & 11.80 & 299.48 & 520.19 & 528.20 & 179.10 & 163.15 & 585.10 & 603.74 & 276 & 274.66 & 232.80 & 205.51 \\
\hline
\end{tabular}

Table 10. Validation of models

\begin{tabular}{lcrrrrl}
\hline Market & $\mathrm{R}^{2}$ & \multicolumn{1}{c}{ MAPE } & RMSPE & \multicolumn{1}{c}{ RMAPE (\%) } & RMSE & Theil's U \\
\hline Cambodia & 0.998936 & 0.014852 & 0.000141 & 0.106419 & 0.044321 & 0.434071 \\
India & 0.999647 & -0.003610 & $1.75 \mathrm{E}-05$ & -0.035330 & 0.013382 & 0.313602 \\
Pakistan & 0.998359 & 0.017071 & 0.000768 & 0.150470 & 0.089406 & 0.267696 \\
Thailand & 0.999801 & 0.001791 & 0.000148 & 0.017949 & 0.089406 & 0.430256 \\
USA & 0.997139 & 0.016145 & 0.001084 & 0.274183 & 0.078366 & 0.524249 \\
China & 0.993522 & 0.052301 & 0.001617 & 0.657370 & 0.114274 & 0.924741 \\
\hline
\end{tabular}

The one-step-ahead-out of the sample forecast of producer rice price for all the selected markets for the period 2018 to 2027 is depicted in Figure 2 and shown in Table 11 . The rice price in the Cambodian market will be marked by a marginal slight increase from 2018 to 2020 and afterward, plummeted in the succeeding period. Thereafter, the trend will be characterized by a marginal fluctuating trend until the end of the forecasted period. The future price trend of the Indian market will witness a marginal rise from 2018 to 2020 and thereafter will marginally decline till 2025. Afterward, it will marginally incline until the end of the forecasted period. For the Pakistan market, the rice price will be marked by a marginally inclining trend from the trough point till 2024 and afterward marginally declined till the end of the forecasted period. In the Thailand market, rice prices will witness a decrease from 2018 till 2023 and afterward slightly inclined (2024); and subsequently will decline in the succeeding period. This declining trend will persist until the end of the forecasted period. The market price of USA's rice will observe a cyclical trend viz. interchangeable slight increase and decrease from the trough period till the end of the forecasted period. The price will 
SADIQ et al.
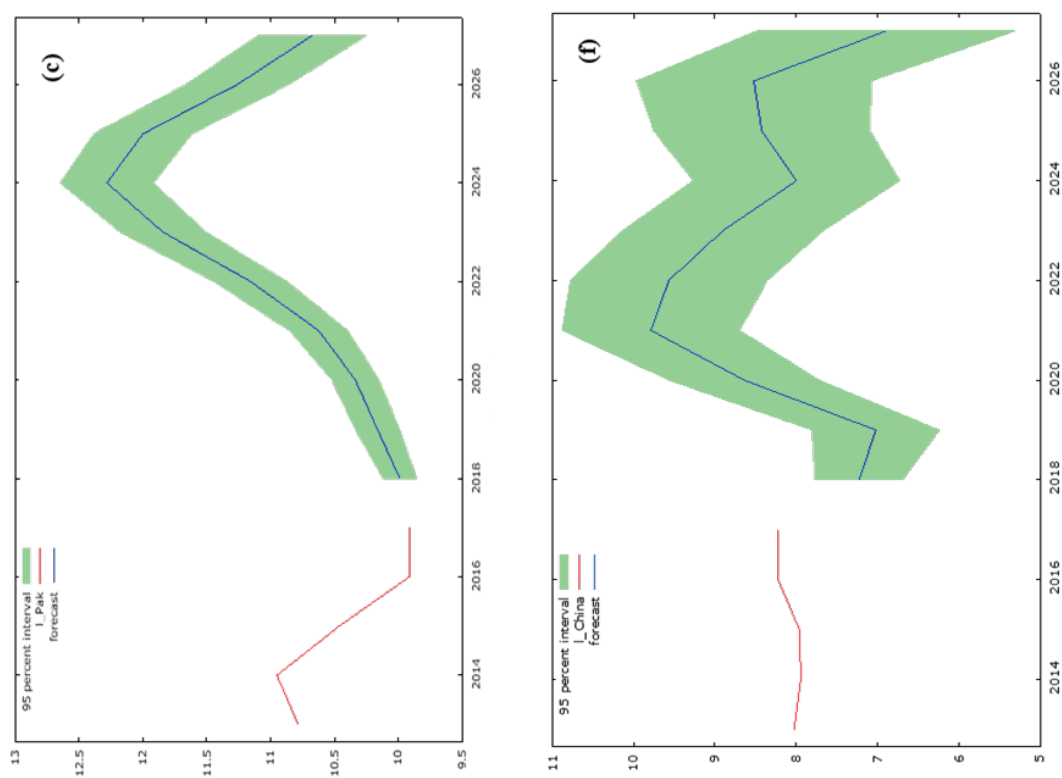

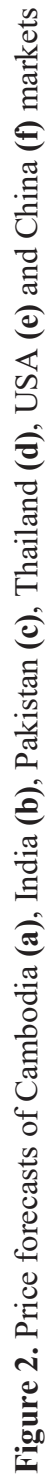
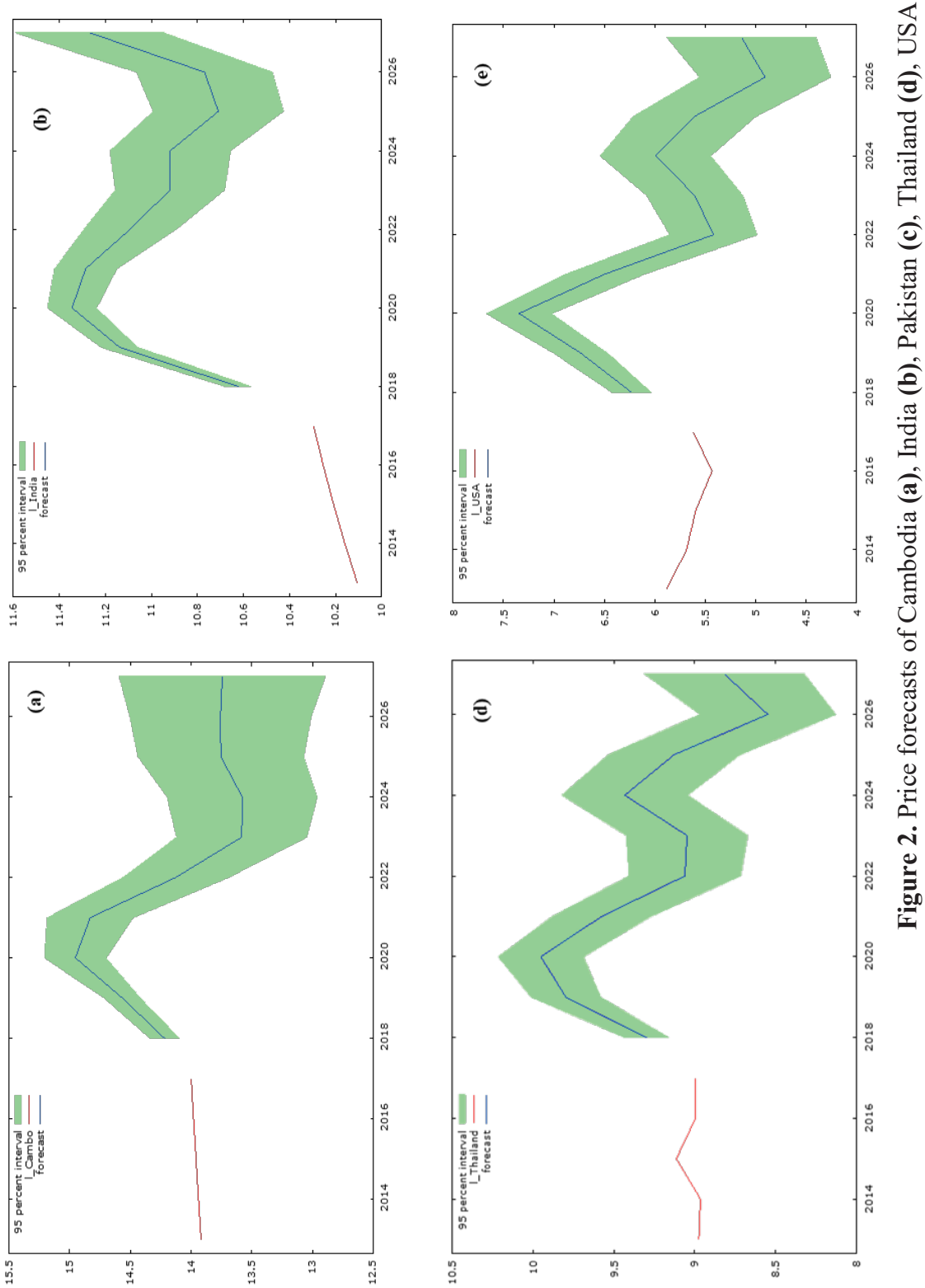

Türkiye Tarımsal Araştırmalar Dergisi - Turkish Journal of Agricultural Research

8(1): 56-74 
Table 11. Out of sample price forecast of the selected markets (\$ per ton)

\begin{tabular}{|c|c|c|c|c|c|c|c|c|c|}
\hline \multirow{2}{*}{ Year } & \multicolumn{3}{|c|}{ Cambodian market } & \multicolumn{3}{|c|}{ Indian market } & \multicolumn{3}{|c|}{ Pakistan market } \\
\hline & Forecast & LCL & UCL & Forecast & LCL & UCL & Forecast & LCL & UCL \\
\hline 2018 & 4672.837 & 4146.512 & 5265.976 & 77.03089 & 72.98037 & 81.30622 & 120.8779 & 106.1427 & 137.6588 \\
\hline 2019 & 6440.770 & 5551.466 & 7472.541 & 125.7445 & 116.1587 & 136.1216 & 143.2792 & 120.5822 & 170.2485 \\
\hline 2020 & 9246.441 & 7181.798 & 11904.63 & 150.7905 & 135.639 & 167.6346 & 169.5102 & 141.1363 & 203.5881 \\
\hline 2021 & 7973.758 & 5599.822 & 11354.09 & 138.8023 & 121.2894 & 158.8439 & 224.5194 & 178.8616 & 281.8323 \\
\hline 2022 & 3836.998 & 2488.891 & 5915.30 & 111.8033 & 91.55876 & 136.5239 & 382.2791 & 287.6484 & 508.0414 \\
\hline 2023 & 2178.731 & 1276.511 & 3718.623 & 91.94135 & 72.58708 & 116.4563 & 752.8332 & 538.4592 & 1052.555 \\
\hline 2024 & 2120.054 & 1143.834 & 3929.439 & 89.80401 & 69.18151 & 116.5738 & 1163.314 & 808.464 & 1673.913 \\
\hline 2025 & 2470.101 & 1249.321 & 4883.767 & 71.3344 & 53.80076 & 94.58214 & 870.7655 & 593.6588 & 1277.218 \\
\hline 2026 & 2421.558 & 1148.867 & 5104.109 & 74.16561 & 55.26836 & 99.52417 & 414.327 & 277.1039 & 619.5037 \\
\hline 2027 & 2334.907 & 998.8958 & 5457.813 & 119.6344 & 86.77041 & 164.9458 & 228.2473 & 149.4186 & 348.6636 \\
\hline \multirow{2}{*}{ Year } & \multicolumn{3}{|c|}{ Thailand market } & \multicolumn{3}{|c|}{ USA market } & \multicolumn{3}{|c|}{ China market } \\
\hline & Forecast & LCL & UCL & Forecast & LCL & $\mathrm{UCL}$ & Forecast & LCL & $\mathrm{UCL}$ \\
\hline 2018 & 18.08252 & 15.78874 & 20.70955 & 509.24 & 420.28 & 617.03 & 5.832287 & 3.411552 & 9.970704 \\
\hline 2019 & 28.92502 & 23.32797 & 35.86497 & 843.34 & 646.46 & 1100.18 & 4.682311 & 2.143521 & 10.22805 \\
\hline 2020 & 32.83504 & 25.22587 & 42.73944 & 1550.94 & 1123.61 & 2140.79 & 23.34643 & 9.29413 & 58.64522 \\
\hline 2021 & 21.9224 & 16.15081 & 29.75651 & 661.86 & 448.29 & 977.23 & 72.92248 & 24.49542 & 217.0889 \\
\hline 2022 & 12.75583 & 9.040779 & 17.99745 & 225.88 & 146.96 & 347.19 & 57.78034 & 17.22419 & 193.8302 \\
\hline 2023 & 12.2626 & 8.428271 & 17.84128 & 272.08 & 169.13 & 437.69 & 29.33491 & 8.536076 & 100.8118 \\
\hline 2024 & 17.57537 & 11.90532 & 25.94582 & 401.22 & 232.40 & 692.69 & 11.74924 & 3.303062 & 41.79296 \\
\hline 2025 & 12.64019 & 8.406049 & 19.00708 & 272.54 & 148.62 & 499.79 & 17.79937 & 4.715147 & 67.19145 \\
\hline 2026 & 6.906393 & 4.539153 & 10.50818 & 135.23 & 70.72 & 258.58 & 19.42328 & 4.592826 & 82.14201 \\
\hline 2027 & 8.825648 & 5.382958 & 14.47012 & 170.87 & 81.77 & 357.09 & 3.790487 & 0.774173 & 18.55888 \\
\hline
\end{tabular}

UCL: Upper confidence limit, LCL: Lower confidence limit

marginally increase between 2018 and 2020, and thereafter marginally plummeted till the year 2023 . In the subsequent period, the price will slightly surge and afterward slightly plummet till 2026. In the succeeding period, the cyclical trend will initiate a revival trend. Similarly, China's market will exhibit a two-fold cyclical trend with the former been thicker than the latter. Between the periods 2018 to 2021, it will exhibit a slight fluctuation and thereafter will slightly decline till 2024. In the succeeding period, a recovery trend will be initiated and will persist till 2026, and thereafter will steeply recess in the subsequent period (2027).

Generally, it can be inferred that the future price trends of all the selected markets will witness low instability, an indication of a low imbalance between supply and demand. In other words, it means that the prices of rice in the selected markets will adjust according to supply and demand.

\subsection{The extent of price volatility}

The pre-condition necessary for the application of the GARCH model was met as all the selected markets had their residuals to have an Arch effect as evident by their respective LM test statistics which were within the plausible margin of $10 \%$ degree freedom (OLS results in Table 2). In addition, the trend behavior of their residuals showed the presence of a clustering effect (Figure 3 ). Thus, having satisfied these criteria; the extent of price volatility was determined using the GARCH model.

A cursory review of the GARCH model showed that different models of various orders fit the selected markets (Table 12). The highest GARCH order was found for the USA market $(1,2)$, i.e. GARCH $(1,2)$ fitted the USA market while the remaining markets were fitted with GARCH $(1,1)$ model. The empirical evidence showed the sum coefficient of 'alpha and beta' for Cambodian, USA, and China markets to be 'closer to one', thus indicating persistent price volatility in these markets. However, the market prices of India, Pakistan, and Thailand were marked by explosive volatility as evident by the sum coefficient of 'alpha and beta' which was 'one'.

It was observed that volatility in the current year rice prices of Indian, Pakistan, Thailand, and China markets depend on both family and international shocks; while volatility in the current price of the Cambodian market depends on only internal shock. However, volatility in the current price of the USA market was independent of both internal and external shocks as evident by the nonplausibility of the coefficients at the $10 \%$ probability level.

In the Cambodian market, volatility in its current year prices was influenced by speculative information on the preceded year price as evidenced by the significance of the ARCH term (i.e. Alpha) coefficient at a 1\% probability level. 


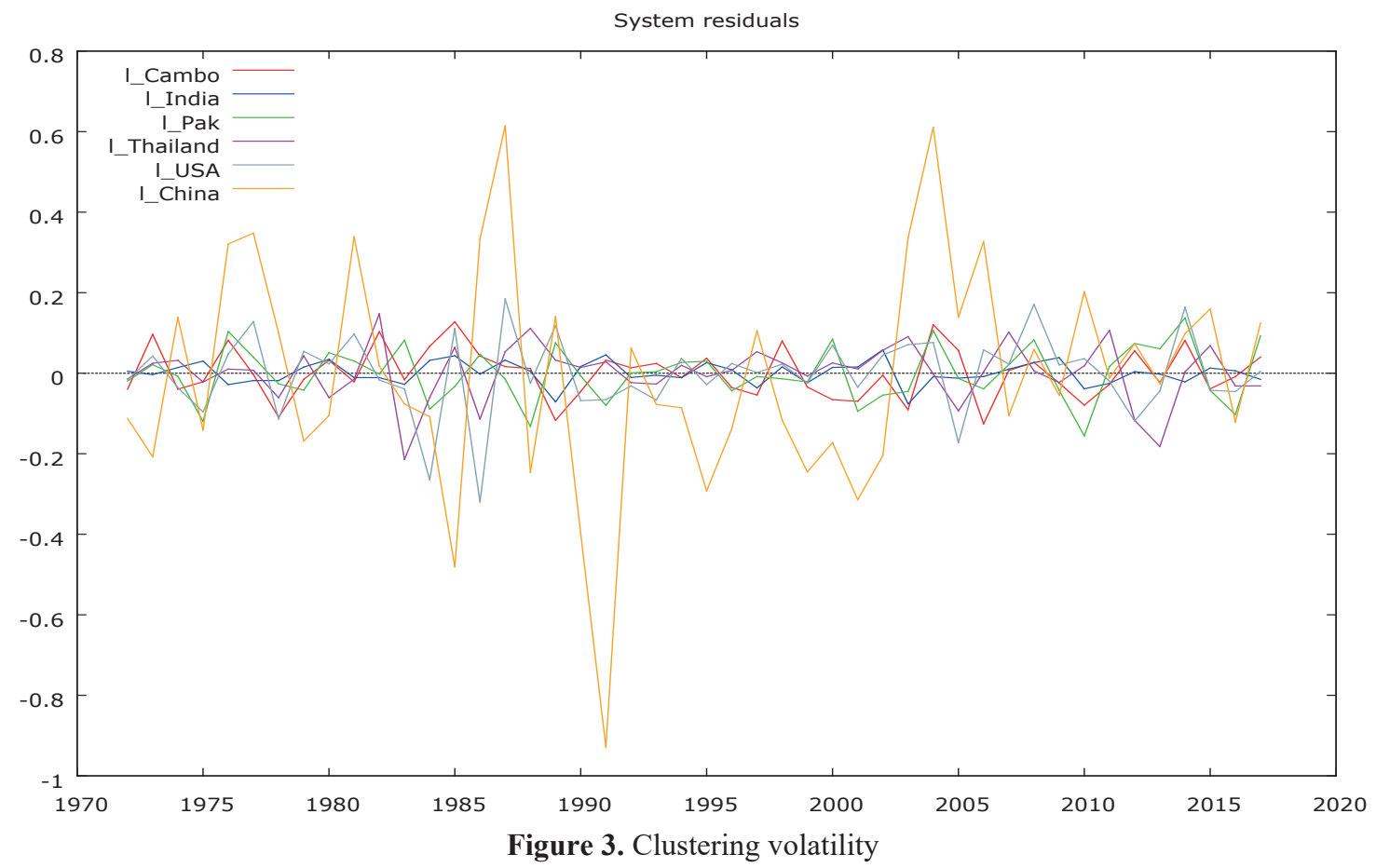

The negative significance of the ARCH term coefficient implies that speculative information about the preceded price behavior of the Cambodian market increased its current price volatility. The volatility in the current year prices of the Indian market was influenced by both arbitrage information and price of the preceded year, and the international shock viz. Pakistan, USA, and China preceding market prices. This is evident by the significance of the ARCH term, GARCH (i.e. Beta) term, and the price estimated coefficients for Pakistan, USA, and China markets that were within the acceptable margin of $10 \%$ probability level. The family shocks, Pakistan, and USA market prices increased the volatility of the current year prices of the Indian market while the China market prices decrease the current price volatility of the Indian market.

In the Pakistan market, its current price volatility was influenced by arbitrage information of the preceded price trend and the prices of all other selected markets as evidenced by the significance of the ARCH effect and parameter estimates for the former and latter at 10 and $1 \%$ probability levels, respectively. Except for USA market prices which negatively influenced the current price volatility of the Pakistan market, all the remaining factors positively influenced the current price volatility of the Pakistan market. The current price volatility of the Thailand market was influenced by its immediately preceding price and market prices of Cambodia, the USA, and China. Both the internal and external shocks increased the current price volatility of the Thailand market. In China market, its current-year price volatility was influenced by speculation information about its preceding year price and USA market price as evidenced by the plausibility of their respective coefficients that are within the margin of $10 \%$ probability level. Both factors increased the current year price volatility of the China market. However, it was observed that the current year price volatility of the USA market was independent of both the family and international shocks as evident by their respective estimated coefficients that are similar to zero at a $10 \%$ degree of freedom.

On comparing price volatilities for the selected markets only a miniscule change was noticed in the value sum of 'Alpha and Beta' coefficients. Thus, it can be inferred that the market prices of rice in Cambodian, USA, and China markets are very useful in the international market. The reason for the quite persistence of volatility in the rice prices of USA and China markets may be attributed to inventory accumulation shocks which generate discontinuity and asymmetric price responses. For the Cambodian market, the price volatility may be due to its nascent stage in the international market of rice. However, for Indian, Pakistan, and Thailand markets, the reason for the explosive volatility may be attributed to barriers to entry, risk aversion, and information failures; thus, generating discontinuity and asymmetric price responses. 


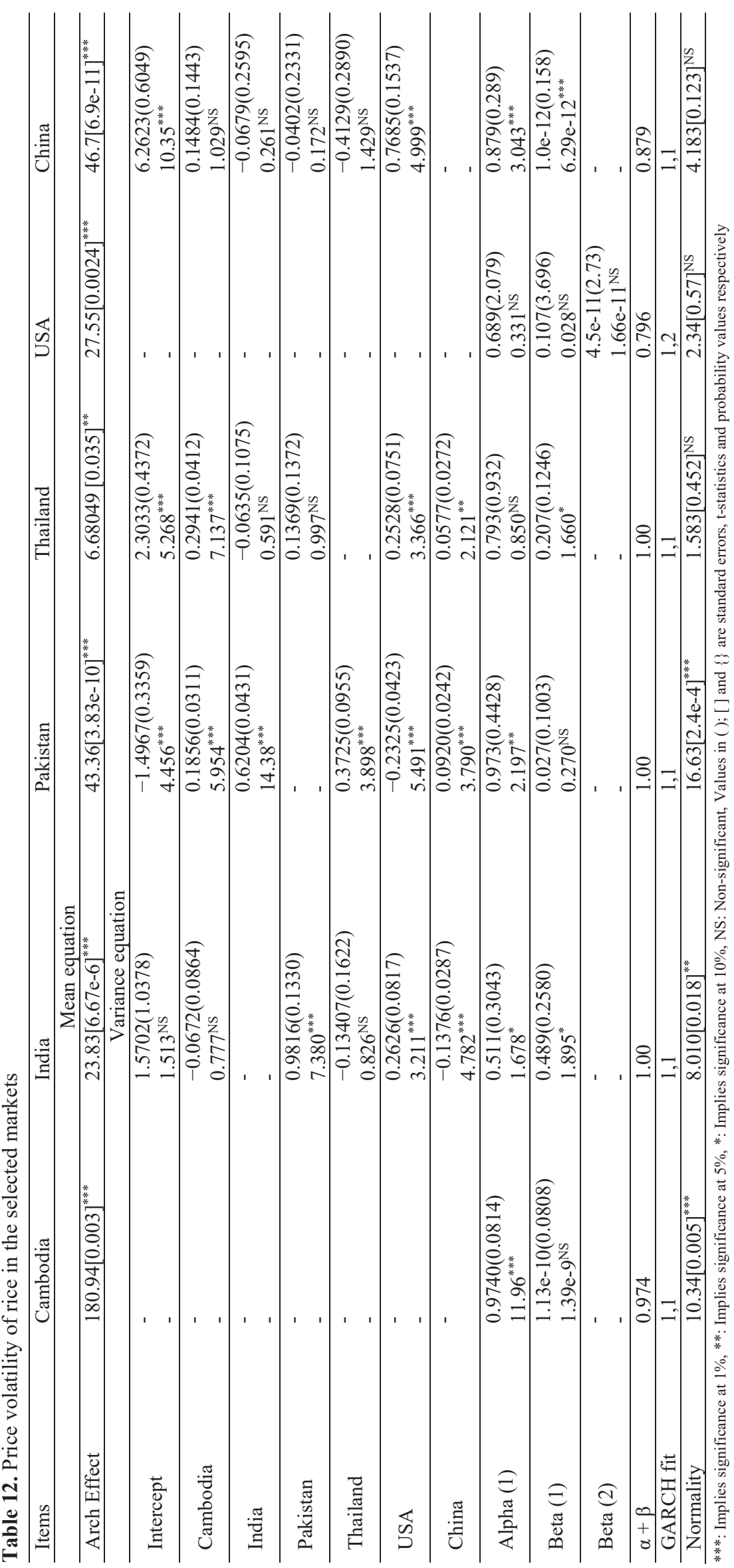




\section{Conclusion and Recommendations}

In view of the above findings, it can be inferred that long-run price transmission exists among the selected markets but the LOP did not hold owing to weak co-integration among the markets. Furthermore, except for Pakistan and China markets, all the remaining markets established a long-run equilibrium, thus efficient as they can absolve any shock that generates discontinuity from any of the short-runs. The non-stability of the equilibrium of Pakistan and China markets may be attributed to asymmetric price responses for the former and leverage effect for the latter whose large production capacity gave it a dominant market power. However, the Pakistan market has a dominant role in influencing the price formation in all the selected markets. Also, the leverage effect i.e. inventory accumulation insulates China market from any unexpected local shocks that will generate discontinuity in the adjustments of prices between markets. Furthermore, it can be inferred that trade in rice marketing has a good prospect for the markets that witnessed persistent volatility in their current year prices. It can be concluded that arbitrage which would create an imbalance between supply and demand, thus affecting price will be minimal in the future price trends of all the selected markets. Therefore, the study recommends the need for enhanced development of market infrastructures, effective adoption of etrade and e-commerce, value addition, transportation, and other back-end supply chain, thus strengthening the linkages and interconnectedness among the selected markets for speedy price communication and commodity management from surplus to the deficit areas of each market region. This will help in the development of a single integrated economic rice market in the world.

\section{References}

Anonymous, 2020. Global Market Analysis. Foreign Agricultural Services/USDA.

Ardeni, P.G., 1989. Does the law of one price really hold for commodity prices? American Journal of Agricultural Economics, 71: 661-669.

Beag, F.A., Singla, N., 2014. Cointegration, causality and impulse response analysis in major Apple markets of India. Agricultural Economics Research Review, 27(2): 289-298.

Engle, R.F., Granger, C.W.J., 1987. Co-integration and error correction: representation, estimation and testing. Econometrica, 55(2): 251-276.

Ghafoor, A., Mustafa, K., Mushtaq, K., Abedulla, 2009. Cointegration and causality: An application to major mango markets in Pakistan. Lahore Journal ofEconomics, 14(1): 85-113.
Granger, C.W.J., 1969. Investigating causal relations by econometric models and cross-spectral methods. Econometrica: Journal of the Econometric Society, 37(1): 424-438.

Hussaini, B., Ashfaq, M., Abbas, M., Mahmood, K., Mahmood, M.A., 2010. Market integration of gram in Pakistan. Pakistan Journal of Agricultural Research, 23(1-2): 78-82.

Johansen, S., 1988. Statistical analysis of co-integration vectors. Journal of Economic Dynamics and Control, 12(2-3): 231-254.

Lanfranco, B.A., Ferraro, B., Rostán, F., 2019. Cointegration and price linkages in the Mercosur beef cattle markets. International Journal of Food and Agricultural Economics, 7(2): 159-174.

Mahalle, S.L., Shastri, S., Kumar, S., 2015. Integration of wheat markets in Maharashtra. Agricultural Economics Research Review, 28(1): 179-187.

Paul, R.K., 2014. Forecasting wholesale price of pigeon pea using long memory time-series models. Agricultural Economics Research Review, 27(2): 167-176.

Rahman, M.M., Shahbaz, M., 2013. Do imports and foreign capital inflows lead economic growth? Cointegration and causality analysis in Pakistan. South Asia Economic Journal, 14(1): 59-81.

Reddy, A., 2012. Market integration of grain legumes in India: The case of the chicken pea market. SAARC Journal of Agriculture, 10(12): 11-29.

Sadiq, M.S., Karunakaran, N., Singh, I.P., 2018 a. Integration of banana markets in India. ICTACT Journal on Management Studies, 4(2): 764-781.

Sadiq, M.S., Singh, I.P., Ahmad, M.M., 2020a. Market integration of sesame seeds in South Asia. Alanya Academic Review Journal, 4(1): 143-155.

Sadiq, M.S., Singh, I.P., Ahmad, M.M., 2020b. The politics of rice production in Nigeria-can Nigeria become a net exporter or will remained a net importer? Economic Affairs, 65(3): 309-322.

Sadiq, M.S., Singh, I.P., Aminu, S., Grema, I.J., 2017. Volatility and price discovery of palm oil in international markets under different trade regime. Journal of Agricultural Economics, Environment and Social Sciences, 3(1): 33-50.

Sadiq, M.S., Singh, I.P.,Aminu, S., Umar, S.M., Grema, I.J., Usman, B.I., Isah, M.A., Lawal, A.T., 2016a. Extent, pattern and degree of integration among some selected cocoa markets in West Africa: An innovative information delivery system. Journal of Progressive Agriculture, 7(2): 22-39.

Sadiq, M.S., Singh, I.P., Aminu, S., Umar, S.M., Grema, I.J., Usman, B.I., Isah, M.A., Lawal, A.T., 2016b. Price transmission, volatility and discovery of gram in some selected markets in Rajasthan State, India. International Journal of Environment, Agriculture and Biotechnology, 1(1): 74-89.

Sadiq, M.S.,Singh, I.P., Singh, N.K., Yakubu, G.M., 2018b. Improving efficiency and TFP of lowland paddy rice farmers in Kwara State of Nigeria. Journal of Agricultural Sciences, 13(2): 110-129. 
Stigler, M., 2011. Commodity prices: Theoretical and empirical properties. In: A. Prakesh (Ed.), FAO Report on Safeguarding Food Security in Volatile Global Markets, 2: 27-43.

Sukati, M., 2017. Analysis of maize price volatility and price pass through in Swaziland: Implications for price stabilization policies. Journal of Economics and International Business Management, 5(1): 1-13.

Workman, D., 2020. Rice Exports by Country. (www.worldstopexports.com/rice-exports-country/), (Date of access: 10.10.2020). 